Florida International University FIU Digital Commons

$11-21-1989$

\title{
Examining the needs for student services of adult learners in continuing higher education
}

Roberto Barragan Jr.

Florida International University

DOI: $10.25148 /$ etd.FI14050435

Follow this and additional works at: https://digitalcommons.fiu.edu/etd

Part of the Education Commons

\section{Recommended Citation}

Barragan, Roberto Jr., "Examining the needs for student services of adult learners in continuing higher education" (1989). FIU Electronic Theses and Dissertations. 1403.

https://digitalcommons.fiu.edu/etd/1403 
EXAMINING THE NEEDS FOR STUDENT.SERVICES OF ADULT LEARNERS IN CONTINUING HIGHER EDUCATION

by

Roberto Barragan, Jr.

A Dissertation submitted to the Faculty of the College of Education

in Partial Fulfillment of the Requirements

for the Degree of

Doctor of Education

Florida International University

Miami, Florida

October 1989 


\section{EXAMINING THE NEEDS FOR STUDENT SERVICES \\ OF ADULT LEARNERS IN CONTINUING HIGHER EDUCATION}

by

Roberto Barragan, Jr.

This dissertation was prepared under the direction of the candidate's dissertation advisor, Dr. Douglas H. Smith, and has been approved by the members of his supervisory committee. It was submitted to the faculty of the College of Education and was accepted in partial fulfillment of the requirements for the degree Doctor of Education.

SUPERVISORY COMMITTEE

Chairperson

Dean, College of Education

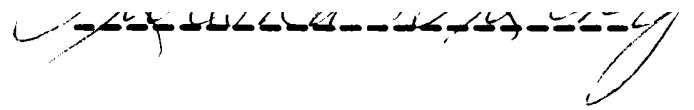

Dean, Graduate studies Mov_ 21,1589 Date 
Author:

Title:

Institution:

Degree:

Year:
Roberto Barragan, Jr.

Examining the Needs for student Services of Adult Learners in Continuing Higher Education

Florida International University Doctor of Education

The primary purpose of this study was to examine the availability and quality of student services offered to adult learners in selected continuing education programs in Dade County, Florida.

The two basic research questions addressed in this study were:

1) What are the student services being provided to adult learners by the selected colleges and universities?

2) What is the quality of these services being provided as perceived by administrators and adult learners at their institutions?

Two groups comprised the population for this study. One group sample of adult learners enrolled in credit courses being offered by the continuing education unit. The second group sample was comprised 
of administrators in the areas of Admissions, Financial Aid, Registration, student Services and Continuing Education at each of the five colleges and universities in Dade County, Florida.

Data were collected from 107 students and 25 administrators using the continuing Education student Services Questionnaire (CESSQ) developed by the researcher in a pilot study.

The questionnaire, one for administrators and a similar one for adult learners, consisted of two parts. One consisted of eight demographic items and the second one of twenty items describing student services.

An overview of responses by institutions showed that only the following services received a $100 \%$ response as available at one or more institutions: 1) Admissions Information, 2) Convenient Hours for Registration, 3) Assistance in Class Registration, 4) Assistance in Planning a Class Schedule, 5) Access to the Library in Evening and Weekends, 6) Parking and Security, 7) Food Services, 8) Bookstore and 9) Access to Computers. 


\section{ACKNOWLEDGMENTS}

Although many people assisted me with their suggestions and encouragement throughout the development of this study, I am especially grateful to Dr. Douglas H. Smith for his direction and continuing support, and Dr. Paulette Johnson for her guidance and willing assistance in data analysis. I would also like to express my thanks to the other members of my doctoral committee, Dr. Luretha Lucky, and Dr. Jethro Toomer for all their help in this endeavor.

The cooperation of the administrators and faculty members who allowed me to distribute my questionnaire to students during their class times is appreciated. I am also grateful to the students and administrators who participated in this study.

To Drs. Adib and Annette Shakir for their encouragement, love and support, I am most grateful.

To Dr. Richard Campbell, who provided the fraternal love and support throughout the three years I thank you.

Finally, this dissertation is dedicated to Dr. Oswald P. Bronson, President of Bethune Cookman College, who allowed me the time, and financial support to complete this endeavor. 
ABSTRACT .............................

ACKNOWLEDGEMENTS .................... v

IIST OF TABLES..................... viii CHAPTER

I. INTRODUCTION $\ldots \ldots \ldots \ldots \ldots \ldots \ldots \ldots \ldots \ldots$

Background of the Problem........... 2

Statement of the Problem............ 7

Purpose of the study.............. 9

Conceptual Framework for this study.... 10

Definitions of Terms............. 15

II. REVIEW OF THE RELATED IITERATURE....... 18

How Adults Learn................ 18

Adult learning and the Changing Needs of

Adult Learners.................. 24

Adult Learning and Higher Education..... 33

Reasons for Returning to school........ 34

Differences Between Traditional and

Non-Traditional Students........... 37

Types of Problems Facing Adult Learners. 40

Services Needed to Help overcome

Barriers Faced by Adult Learners....... 41

overcoming Situational Barriers.... 42

overcoming Dispositional Barriers.. 43

overcoming Institutional Barriers.. 46

Summary of the Review of the Literature. 48

III. METHODOLOGY.................. 52

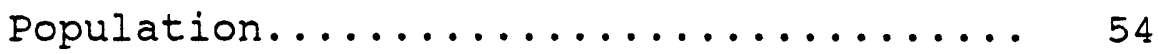

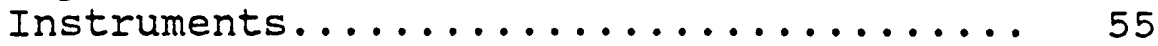

Data Collection Procedure.......... 55

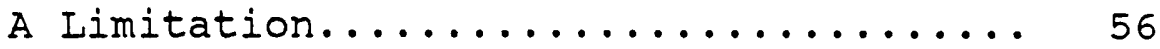

Analysis of the Data................ 57

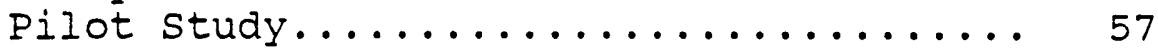


IV. PRESENTATION OF RESEARCH FINDINGS...... 59

Population of This study............ 60

Adult Learners Respondents........ 62

Administrator Responses.......... 65

Adult Learners' and Administrators'

Perceptions of student Services being

Provided...................... 67

Adult Learners' Perceptions of

student services.............. 69

Administrators' Perceptions of

student services.............. 74

Adult Learners' and Administrators'

Perceptions of Quality of student

Services.................... 76

Administrators' Perception of Services

Provided to Adult Learners versus

Traditional students.............. 82

Comparison of student Services

Importance and Availability......... 84

V. SUMMARY, CONCLUSIONS AND RECOMMENDATIONS. 89

APPENDICES

A. Continuing Education student Services

Questionnaire (Administrators)......110

B. Continuing Education student Services Questionnaire (Adult Learners).......114

c. Continuing Education Students

Student Services Survey used in the

Pilot study..................17

D. Dean of Continuing Education

Questionnaire used in Pilot study....120

E. Summary of Pilot Study Responses.....122

F. Letter to Dean of Continuing

Education Programs...............123

G. Letter from Dr. Smith to Deans of

Continuing Education Programs.......124 
H. List of Individuals to Receive

Letters Requesting Permission to

Administer Questionnaires..........125

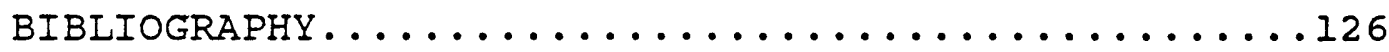

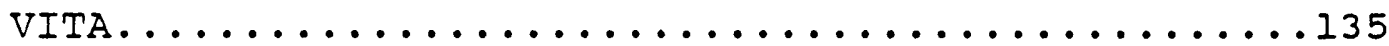


1 Characteristics of Traditional vs Non-traditional student............ 38

2 Number of Participants in the study...... 62

3 Biographical Data of Adult Learners...... 63

4 Biographical Data of Administrators...... 66

5 Percentage of Adult Learners Indicating Student Services Provided by Institutions. 70

6 Percentage of Administrators Indicating student Services Provided by Institutions. 72

7 Percentage of Administrators' and Adult Learners' Perception of the Quality of the Student Services Provided by Institutions.

8 Percentage of Administrators Indicating Similarity of Services Provided to Adult Learners and Traditional students........

9 Comparison of student Services Importance and Availability................. 86 


\section{INTRODUCTION}

The concept of lifelong learning and the concept of a nontraditional approach to study started as a trend for many post-secondary educational institutions during the 1970's and has continued through the 1980's. The need to attract an adult clientele to replace the decreasing traditional college-adult population, has resulted in an increasing number of nontraditional programs on college and university campuses. Many of these programs have been introduced without much investigation, thought, or pre-planning and are enjoying varying results of success, from moderate growth to frustration and failure.

According to silling (1984), the number of adults taking advantage of opportunities in higher education is increasing at a substantial rate. Between 1970 and 1980, adults in college between the ages of 30 and 34 increased by 179 percent (Babcock, 1982). A survey conducted by the college Board reports that students over 25 years old comprise 45 percent of all campus enrollments (Hirshorn, 1988). Within the next decade, the College Board predicts that figure could rise to 50 percent.

A need exists, therefore, to carefully examine 
these trends in adult enrollments and its impact upon colleges and universities. This study examined the services being provided to adult learners and how those services are being met at five institutions of higher education in Dade county, Florida. Factors contributing to the rise of its current adult student population were investigated to determine the impact upon the student services provided at the five institutions. Background of the Problem

A number of factors explain why there has been such a rise in the number of adult students on campuses. These factors can also assist in predicting enrollment trends in the next ten to fifteen years. Six factors further investigated in this study were: changing population structure, the status of women, governmental decisions, inflation and recession, ambivalence toward education, and the consumer movement.

Changing population structure. The median age in the United States in 1985 was approximately 31 years, up from a median age of 28.8 in 1975. At this rate, the median age in the United States by 1990 is projected to be 32.8 (Mills, 1985). As the number of 
adults over the age of 25 increases it is projected that the number of adults in higher education will also increase.

Colleges and universities in many areas have already begun to aggressively recruit adult students. This has generally been done in response to declining numbers of traditional students aged 18-21. According to Hechinger (1985), the numbers of Americans aged 1821 were at an all time high of 17 million between 1975 and 1980, but by 1990 the number in this age group will have decreased to 13.5 million. If these predictions prove to be valid, many institutions of higher learning will have to increasingly rely on adult students if they are to continue to operate at current levels.

Status of Women. Women aged 35 years and older are returning to education at an increasing rate. The women's-movement has made it much more acceptable for women to seek self-sufficiency and fulfillment in their lives. Because they are growingly being accepted as part of the labor market, many are returning to school in order to begin, or change careers. Others are attending as a result of divorce, to reduce the boredom of being at home after children 
are in school or grown. Middle-aged women represent the fastest-growing student population in the last several years, and will probably continue to be as long as new roles and opportunities for women are available within our society (Brandenberg, 1974). Governmental Decisions. Changes in state and federal policies have a direct effect on the numbers of adults who enroll in higher education programs. For example, state and federal monies to higher education in the form of institutional subsidies and financial aids to students have been steadily decreasing in recent years despite increased costs. This has kept many adults from either beginning or continuing their education. Tight budgets have also meant that colleges and universities have been unable to expand their programs and services for adult students. When considered in light of the expectations of adult students as consumers, this has further discouraged a number of adults from higher education (House, 1983).

Inflation and Recession. The economic fluctuations occurring in the United States have greatly affected the numbers of adults in higher education. Many adults have lost jobs in industries 
being phased out, finding it necessary to retrain for new occupations (Eurich, 1985). Others find that promotions and salary increases are dependent upon new skills or earned degrees. Increased living costs have lead to a dramatic increase in the number of twocareer couples.

In the past 10 to 15 years, 40 million new jobs were created as baby boom males reached working age in the 1970s and 1980s, and what few had foreseen, married women came into the labor force in great numbers (Title \& Denker, 1980). Economic growth absorbed this unexpectedly large influx through the creation and growth of jobs, which in turn created a need for training.

While jobs were being lost in traditional sectors such as manufacturing, government, education and hospitals (the large institutions), new jobs appeared in small to medium sized companies. The workers being displaced from the declining industries needed retraining, but they are a far smaller group than those in newly created jobs requiring new skills. of the 40 million new jobs created in the past fifteen years, only 5-6 million were in high-technology areas (Eurich, 1985). 
Therefore, a number of corporations have found it advantageous to provide employees with educational opportunities in the work setting. In some instances, the teaching is coordinated between the company and a local school. Increasingly however, this type of education in non-school settings may be conducted solely by corporations. Thus, corporations will be in direct competition with colleges and universities for adult learners, with the potential of further reducing enrollment figures already suffering from declines in the number of traditional students (Bettandorff, 1980).

Ambivalence Toward Education. The type of educational programs offered to adult learners will affect the numbers of adults attracted to higher education. Many adults are in favor of an education that is practical and quickly applicable to career objectives. Others want a broad background and application to lifelong learning goals (De Crow, 1975). Institutions that can maintain flexibility and offer programs to meet both expectations will likely attract larger numbers of adult learners. Other institutions may choose to specialize in one area over another depending on the desires of potential adult 
markets in their area. Corporations are more demanding and have more sophisticated expectations about what training should entail. They want practical programs tied to corporate goals and their expectations are affecting training methodologies.

The Consumer Movement. As consumers, adults paying tuition expect a certain "return on their investment", much as they would if they were purchasing material goods. In addition to expecting quality teaching in the classroom for their money, they are also demanding quality student services as a secondary benefit. Whereas younger students tend to adapt their expectations and behavior to fit with the established academic status quo, adult learners will motivate institutions to adapt to their needs if they are to be retained in large numbers (Silling, 1984). Statement of the Problem

student services provided to adults contributes to the retention of adult learners. The delivery of these services is recognized as being of critical importance in the field of continuing higher education.

A number of services and programs can be implemented by colleges and universities to assist 
adult learners to overcome the barriers they face when returning to school. Even though a number of studies have been done that examine the services being provided, and will be discussed in the next chapter, a number of questions have not been addressed, particularly questions regarding the quality of the services provided to adult learners.

This study examines the availability and quality of student services offered to adult learners in selected continuing education programs in Dade County, Florida. The two basic questions addressed in this study were:

What are the student services being provided to adult learners by the selected colleges and universities?

What is the quality of these services being provided as perceived by administrators and adult learners at their institutions?

From these two basic questions, six research questions were formulated, developed and tested. Those questions were:

1. What are the services being provided to adult learners by the five colleges and 
universities?

2. What is the quality of the services being provided as perceived by the administration?

3. What is the quality of the services being provided as perceived by the adult learners?

4. Are there any differences in the services being provided to adult learners by the five colleges and universities?

5. Are there any differences in the quality of the services as perceived by the administrators and adult learners?

6. Are there any differences in the services provided to adult learners versus traditional college age students?

Purpose of the study

This study examines the services being provided to adult learners enrolled at five colleges and universities in Dade County, Florida, in order to recommend desired services for adult learners.

Factors contributing to the rise of current adult student population in colleges and universities were investigated, and their impact on the student services being offered. Factors such as, reasons for returning to school, and differences between traditional and 
nontraditional students were examined. Additionally, institutional, situational and dispositional barriers confronting adult students were explored.

The institutions were selected for the size of their enrollment, mission and design of their respective continuing education programs, as well as their location. Being in the same county, they essentially recruit from the same adult population.

The five institutions were studied to determine their above mentioned characteristics, as well as a comparison of student services offered to their general (full-time) student population versus their adult population. Conceptual Framework for this study

The concept of student services has evolved empirically out of efforts to correct situations that interfere with the full development of students. Such a human impulse to help someone in difficulty is found in many cultures and is explicit in the JudaeoChristian view of human life (Farmer, 1967). The student personnel philosophy of American higher education has some aspects in common with broader systems of thought. It is not, in itself an articulate and explicitly organized philosophy about 
human development and human values. Nevertheless, some major aspects of its point of view can be identified.

First, a number of years ago, Cowley (1938) used the term "holism" to denote a central concern with all aspects of the development of human individuality. He stated that people do not restrict their effort to intellectual development alone, even though this is essentially the major concern and belief of many educators.

A second aspect concerns the unique individuality of people (Mead, 1936). As applied to adult learners, it is true that selective admission processes reduce the full possible range of individuality to be found in the colleges. There is, however, a tremendous variety of different and unique human beings. The centering of attention and service upon the individual is in itself a reaction to, and protest against, mass education with the consequent neglect of the individual.

A third aspect is the assertion that teaching in the classroom is not enough, or is not sufficient in the education of some students. The experiences of higher education institutions indicate the need of 
some services for some students, supplemental to the classroom, laboratory, and library. The rehabilitation of failing students of high potential ability, for example, and the prevention or misuse of abilities are important areas of services (Paterson, 1957). It seeks to avoid, if possible, wastage of human resources by organizing both preventive and remedial services in education.

A fourth aspect concerns the use of methods and relationships of an educative rather than an authoritarian or chain-of-command type. This is related to the general democratization of higher education for students which has been so clearly evident in the past three decades, ever since World War II brought to the campus more mature students with increasing demands to participate in institutional decision making.

A final aspect is the incorporation into student services of new knowledge of human nature and its development. Such new information comes from the psychology of learning, the psychology of affective behavior, aptitude, and mental health, which collectively provides appropriately new and rich understandings about human development. 
Until recently, adult learners were viewed like other degree oriented students, except they were older. Adult learners have been identified, recruited, educated, and certified much as any other student. Age, developmental phase, gender, and other maturational concerns have been seen as irrelevant to the educational tasks at hand (Weathersby, 1980).

In contrast to that view of adult learners, the pioneering work of Levison (1978), Gould (1978) and Neugarten (1979) provide a framework to analyze data on adult learners. From this research, the following conclusions can be made:

1. Adult learners have at each age-normed phase of their life cycle particular developmental that must be faced, worked on, and resolved.

2. Adult learners encounter basically the same set of developmental tasks over the life cycle, but the way they perceive, react, act upon, and resolve those tasks vary.

3. Encountering the developmental tasks of each phase in the life cycle is fundamentally a learning process: each adult must decide, sometimes carefully and unconsciously, how he/she will respond to the challenge, risks, 
and opportunities presented by the developmental tasks.

4. Adult learners also vary considerably in their educational needs over the life cycle: in part, educational needs are shaped by the particular developmental tasks found in each phase.

5. Formal educational programs, those we know in colleges and universities, have unique opportunities and responsibilities to facilitate adult learning leading to the resolution of developmental tasks in each phase.

To meet a primary trend of the 1980's and beyond, the aging of college students, institutions of higher education will have to adapt to meet the needs of mature students. Higher education has often not been adequately flexible to provide an environment conducive to adult learners. Many faculty need to adjust their teaching to an experimental problemcentered style that often contradicts years of conditioning of teaching through lecture and discussion.

student services provided to adults could be a 
link in the chain of much needed research in the retention of adult learners. This problem is recognized as being of critical importance to the field of continuing higher education.

Even though a number of studies have been done that examine the services provided to adult learners in higher education institutions, a number of questions were not addressed, particularly questions regarding the quality of the services provided to adult learners. It is this area of the quality of services provided that his study is based. Definition of Terms

The following definitions are intended to assist in ensuring the operational purpose and parameters of this study.

Continuing Education. Implies, in the broadest sense, programming and services for pursuing higher education beyond the point where students left formal schooling. It underscores the ideal of continuous learning throughout one's lifespan. Colleges and universities, as well as many professional organizations, generally refer to their adult education activities as continuing education, while public school systems more frequently use the term 
adult education (Darkenwald \& Merrian, 1982).

Student services. Those services provided to students by educational institutions for the purpose of helping their academic development, as measured by the continuing education student services questionnaire (CESSQ), the survey instrument used in this study.

Traditional College Age student. A student of 18 to 23 years of age who is enrolled in a full time course of study in a degree granting institution. Administrator. Refers to administrators in the area of student affairs, such as Director of Admissions, Director of Financial Aid, Registrar, Dean of Student Affairs, as well as Academic Administrators like Dean of Continuing Education and Dean of Academic Affairs.

Five Colleges and Universities. For the purpose of this study, five institutions of higher learning offering at least a baccalaureate degree, and located in Dade County, Florida. The specific institutions in this study are: Barry University, Florida International University, Florida Memorial College, st. Thomas University and University of Miami. Quality. A service perceived as being of quality 
will be those services that have an average of 3.0 or higher on an evaluative instrument, with one (1) being poor and four (4) being exceptional.

Adult Learner. In this study, the term adult learner is intended to apply to persons over 24 years of age, and who are enrolled in any credit courses of study, whether special or regular, to develop new skills and qualifications, or to improve existing skills. This chronological time frame is selected because at age 24 many adults attending traditional colleges, have completed a program in higher education or have become established in their first vocation. 
II. REVIEW OF REIATED IITERATURE

This study examines the services being provided to adult learners enrolled in selected continuing higher education programs at five colleges and universities in Dade County, Florida. In this review of related literature, two primary areas are examined. First, a review of studies on the lifespan of adult learners is presented, focusing on how adults learn and the major differences in the needs of adults in the past $20-30$ years. The second purpose is to review the literature pertaining to the characteristics of adult learners, the differences between traditional and non-traditional students, the types of problems facing adult students and the services needed to help overcome the situational, dispositional and institutional, barriers of adult learners. How Adults Learn

There are a number of useful references in the literature on the theories of adult learning, how adults learn, various aspects of adult attitudes toward learning, and recommended methodologies to facilitate adult learning.

Peters and Boshier (1976) submit useful distinctions in terminology regarding the adult's 
attitude toward learning. They define and correlate needs, interests, and motives as follows:

Needs describe the gap that exists between the current state of the learner and some desired condition, whereas interests are expressions of preference among alternative experiences. Together, they reflect the adult's belief system, past experience, habits, and immediate social situation. Together, they determine the motives for participation in adult education (p. 198). The authors concluded by emphasizing that "adult education programs should be established on the basis of the needs, motives, interests, and expectations of the clientele" (Peters and Boshire, 1976, p. 211). Wedemeyer (1974) presented a different view of adult learning theory. He selected a developmental concept and took into account the informal as well as the formal learning experiences throughout one's life. Social factors, dependency, and autonomy are considered. Thus, the three stages of learning are identified as "I) survival learning 2) surrogate learning and 3) independent or self-directed learning" (p. 115) .

Arenbery and Robertson (1975) revealed useful 
information about the learning abilities and patterns of the older adult. The authors report positive factors regarding primary memory retention, recommendations on self-pacing by the older learners, suggestions for organization of information into secondary memory retention use, and factors to assist in retrieval of information.

Vief (1976) verified the learning ability of older adults,'stating that:

by studying the same people for a long period of time, intelligence appears to increase or remain stable at least until age 60. Even thereafter, stability and increase are often observed as long as people are not affected by debilitating disease or confined to unstimulating environment (p. 5)

Vief believed that the decline in intellectual ability has a direct correlation with the lack of environmental stimulation, and that cultural bias plays a large part in implying that the elderly cannot learn.

Rauch (1972) reported similar findings, stating that adults can learn anything, whatever the age, although it may take a little longer after middle age 
and the methodology may have to be different. He attributes some of the differences to the experiences of the learners of middle and older age. Because that group may know more about some parts of a subject than others, the learning situation should be modified.

Decrow (1975) and knowles (1982) are in agreement with Rauch's beliefs, and offer several additional points. They state that older learners are often the best learners because of their having more and better experiences upon which to base new information. Both authors believed the slight decline in mental ability is usually in relation to speed. The more significant decline is related to profound health problems.

Decrow (1975) offered pertinent information relative to course attendance. He felt that attendance problems frequently attributed to lack of interest are often due to failure to locate or contact the audience. He saw such a situation as a need for: "Learning experiences to be tuned to the style of the particular group" (pp. 12-13).

Several educators have presented valuable information on appropriate methodology for teaching the adult learner. Tough (1971) has given much attention to teaching methods, including plans for 
improving self-planned learning.

Houle (1964) is responsible for pertinent information directed to and for the adult learner. His work is founded on research and experience and contain clearly stated operational ideas. Houle further believed that, "Learning always begins with a definition of a need or interest which gives rise to a goal, which then prescribes not only the learning process but also the method of measuring results" ( $p$. 52 ) •

Kreitlow (1976) approached adult learning by discussing different instructional methods. He recognized the importance of the teacher as the key to learning, and continued with a variety of techniques that teachers may employ with adult learners in various learning situations. A dominant thread of Krietlow was that adults learn in a variety of ways.

Darkenwald and Merriam (1982) list eight such ways:

1. Adults readiness to learn depends on the amount of previous learning.

2. Intrinsic motivation produces more pervasive and permanent learning.

3. Positive reinforcement of learning is more 
effective than negative reinforcement.

4. To maximize learning, information should be presented in some organized fashion.

5. Learning, especially with regard to skill development, is enhanced by repetition.

6. Meaningful materials and tasks are more easily learned and longer remembered than nonmeaningful or nonsensical material.

7. Active rather than passive participation in the learning activity enhances learning.

8. Environmental factors affect learning. Tangible stimuli such as noise, crowded seating, temperature, lighting, etc., can interfere with the learning process (pp. 110-111).

Numerous basic guides on adult learning are found to assist the adult educator. Knox (1977) emphasized that "Iearning achievement is modified by various characteristics of the individual and the learning context. Included are physical conditions, social adjustment, content relevance, pacing, socio-economic status, social change, and personal outlook" (p. 464). Decrow (1975) was convinced that "older adults will learn when the program is meaningful, suited to the 
styles of later life and, especially when they themselves initiated and guide the experience" (p. 1). Grabowski (1976) believed that educators have sufficient knowledge from previous studies to conclude that there are definite patterns of motivation to adult learning. However, he saw limitations when the information may not necessarily apply to a particular individual, and what motives may undergo change.

In summary, the review of the literature on how adults learn indicated that adult learning is a complex phenomenon. While adult learning shares commonalities with childhood learning, there are at the same time substantial differences that necessitate approaching adults, as learners, differently from children as learners.

The adult's independent self-concept, ability to be a self-directed learner, readiness, and orientation to learning are interactive factors that help explain not only the great diversity among adult learners, but also many of the commonalities. Adult Learning and the Changing Needs of Adult Learners.

A number of studies describe the varying needs of adult learners, with many studies utilizing the 
analysis of entire lifespans of adults. Knox (1977) reported on the needs of adults in terms of societal and individual expectations. He identified societal needs and goals as part of one environment. knox believed educational programs for adults fail to deal with biological needs, but relate primarily to societal needs, relative to time, place, and circumstance.

In keeping with numerous lifespan psychologists, Goulet and Baltes (1970) strongly advocated the interdisciplinary approach to seeking additional knowledge regarding lifespan developmental psychology. They stated that "in this context it should not be overlooked that the tendency to take a life-span look at ontogenetic change is not idiosyncratic to psychology" (p. 20). They identify the fields of biology, medicine, psychology, sociology, and education as having much in common in contributing to this undertaking, saying: "The introduction of adult education will significantly alter the type of age functions to be expected in lifespan research on cognitive functioning in future generations" (p. 20). Knox (1977) saw the identification of needs being aided by going to the potential adult client, and by 
seeking the input of experts. He distinguishes the adult learners from youth, characterizing the former by (1) autonomy and (2) application. He stresses the use former "methodological rigor and judgment balance" (p. 23) in assessing adult educational activities. Like Knox, Sinick (1976) also favored a lifespan approach to the study of adults, since it "plays up continuity within the succession of time frames, and lifespan favors segments and their articulation" (p. 100). He lists several pertinent objectives for Iifespan counseling, which are also appropriate for all adult education practitioners.

1. To raise the consciousness and the understanding of personnel and guidance workers (practitioners) regarding the adult and aging stages of human development.

2. To enhance understanding and competence in dealing with clients (adult learners) with respect to second careers, retirement, preretirement and death and dying.

3. To increase appreciation of special considerations in life-span counseling (education) with women and minority groups.

4. To acquire helping personnel with pertinent 
issues and trends with actual and desirable policies and practices so that life-span counseling (education) in the future may be an improvement over the past and the present.

5. To increase counselors' and other workers' recognition of the need for the young to understand the old and to plan for aging (p. 101).

Bischof (1976) reacted to the relevance and usefulness of early studies in the field of lifespan counseling as well as the more recent findings. He refers to Donahue's (1955) concerns expressed in her study.

We should stop lumping all older people together. Perhaps the reason the older group (50 and above or 65 and over) is so frequently lumped together, is because it is the young people who do the studies. Their perception of the differences between 50 and 60 years of age is not as clear to them as it will be when they are grown older too (p. 43).

Donahue was obviously referring to the older adult, but her prevailing concern had broad implications 
regarding the insufficiency of knowledge in adult development.

Buhler (1961) presented her views of psychological maintenance of the adult during the mature years. She sees this function as being twofold: one as the tendency to need satisfaction (discharge), the other as the tendency to uphold the internal order. She identifies four basic tendencies of life: (1) need-satisfaction, (2) toward adaptive self-limitation, (3) toward creative expansion, and (4) toward the upholding of the internal order ( $p$. $364)$.

Regarding the needs of adults, knowles (1982) devoted much attention to adult needs, particularly their educational needs. He believes that "the primary and immediate mission of every adult educator is to help individuals satisfy their needs and achieve their goals" (p. 23). He stresses relevancy and motivation as specific factors that affect the interest of the learner. Knowles (1982) submitted his interpretation of need in behavioral terms, describing need as a want or desire and distinguishing an interest as a liking or preference. He divides needs into two basic categories, "(1) basic or organismic, 
and (2) educational" (p. 80). Although he treats them differently, he believes that both types of needs are important to the adult educator's growth.

Neugarten (1968) also felt strongly about the need for a useful theory on the psychology of the human lifecycle. Neugarten and Datan (1973). addressed themselves to many of the sociological aspects of the Iife cycle by saying that, "The lifecycle can be described as a succession of social roles, and personality can be described as the product of changing patterns of socialization" (p. 56). They also looked at the lifecycle through the three dimensions of time-life time, social time and historical time. They presented a focus on the significant cultural changes within our society and how they have affected the roles of adults.

Neugarten (1968) has researched and written much on the psychology of adulthood and states, "There is at least some evidence... that personality change can occur all along the lifespan; and that any personality theory which is to be useful to us in comprehending the life-cycle must take account of change in advanced old age as well as in other periods of life" (p. 141). It is useful to look at the need of adults in the 
past two or three decades, to examine recent changes in adult living and learning. Lengrand (1975) addressed himself to the many aspects of change in the lives of adults over the past 20-30 years. He did so on a world-wide scale without losing sight of the individual. His experience as an international educator gives considerable meaning to his statements. Lengrand initially recognized the impact of the growing pace of change.

Lengrand stated that:

Innovations which formerly called for sustained effort by several generations are now accomplished by one only. From decade to decade, man is faced with a physical, intellectual and moral universe so vastly transformed that yesterday's interpretations no longer meet the need (p. 26).

Lengrand (1975) recognized many societal changes influencing adult needs. These changes are:

1) The rapid growth of population, 2) increased demand for education, 3) longer life expectation, 4) needs to preserve and utilize natural resources wisely, 5) evolution of scientific knowledge and technology, 6) changes in the 
political realm, and 7) greater volumes of information and changes in life patterns and relationships (p. 33 ).

Lengrand (1975) further stated that, "Patterns of life themselves have been shaken, it would seem as if humanity had cut its moorings and launched out towards an immense adventure of which neither the field of operation nor the objectives to be gained can be perceived with precision" (pp. 36-38).

Tyler (1977) shared his insights on changes over the years and cites the influences of the home as being greatly diminished. He states that when growing up in contemporary society, the limited opportunities to learn through work, and to learn from adults, has had far-reaching effect. Schools have assumed a more meaningful and vital role in preparation for the world of work. This also places greater responsibility on the educational institutions in the education of adults.

Bengtson (1973) recognizes significant changes in the lives of adults over the past decades and reacts to them in the context of biological, psychological and sociological events. He sees those three factors as being contributors to identifiable behavioral 
differences (pp. 8-9).

In summary, the review of the literature on adult learning and adult needs within the changing lifespan of adults shows a variety of ways to approach this area of study. Knox (1977) reported on the needs of adults in terms of societal and individual expectations, relative to time, place and circumstance. However, Goulet and Baltes (1970) strongly advocate the interdisciplinary approach to seeking additional knowledge regarding lifespan developmental psychology, while sinik (1976) favors a longitudinal approach to the study of adults. Buhler (1961) presented her views of psychological maintenance of the adult during the mature years. She identifies four basic tendencies of life: (1) need satisfaction, (2) toward adaptive self-limitations, (3) toward creative expansion, and (4) toward the upholding of the internal order. Bengtson (1973) recognized significant changes in the lives of adults over the past decades and reacts to them in the context of biological, sociological and psychological events.

All these factors play an important role in the behavioral differences of adults within the higher 
education environment. This is the focus of the next section. Adult Learning and Higher Education

It will be helpful at this point to provide some demographic information on the current adult student population in colleges and universities throughout the United States. Apps (1981), identified the adult learner in higher education as predominantly female, white, between the ages of 25 and 39 , and from urban. or suburban areas or small towns. Although hispanics are represented in proportion to the general population, blacks are underrepresented. Women returning to school are likely to be divorced or never married and, if they have children, they are usually younger than age eighteen.

Considering the factors affecting adult student enrollment trends, some of these data may change significantly in the next decade. For example, as the number of elderly in the U.S. increase, many may seek self-fulfillment and relief from boredom in college coursework, thereby increasing the age range of the majority of adult students. In addition, problems of unemployment, and the changing nature of the blue collar industries may encourage more men to look to 
college degrees for retraining, Alford (1980). Reasons for Returning to School

Cross (1981) reported that reasons cited by adults to enroll in higher education have a direct correlation to the reasons that adult students give for returning to school after absence of a number of years. Four categories of reasons are typically cited by adult learners. Scott (1980), Lechworth (1970) and Apps (1981) agreed that, although some individuals return for specific reasons, most return because of a combination of the following four factors:

Identity Crisis. According to scott (1980), many adults are drawn to college in an attempt to develop a more far-reaching identity. During the middle-age years, individuals often question their own abilities and limitations, values and attitude in a collegial environment, they seek a means to attain a better sense of themselves and expand their concept of how they fit into society.

Preparation and Advancement of a Career. Apps (1981) reported that most adult students cite preparation for a career as one of the most important reasons for continuing their education. 
Sometimes their goals are to learn new skills or earn degrees required for promotions and salary increases. Scott (1980) cited that for many women, returning to school offers the opportunity to fulfill personal needs to prove their worth in roles besides those of housewife or mother. Greater Realization or Personal Potential. Many adults go to college because of an interest in developing life-styles that gives life more meaning and makes life more enjoyable. Because society places value on a college degree, increasing numbers of adults are seeking the status of being a college graduate (Scott 1980). Many women begin college immediately after high school, but leave prior to completing a degree in order to get married and have children. Returning to school fulfills a need to complete this unfinished part of their lives providing an opportunity to develop a new set of relationships and skills (Letchworth, 1970). Iife Transitions. Apps (1981) cited a study completed by the college Board which found that 83 percent of adult students polled returned for a college education due to a major life 
transition. Many adults who are divorced or widowed seek new friendships, additional incomeproducing skills, and insurance for a more stable future. Others seek less tangible rewards such as skills in decision-making and assertiveness, or renewed belief in themselves as whole and adequate persons. Hirshorsn (1988) reported that traditional-age students generally cite preparation for a career and desire to move away from home as primary reasons for attending college. Many eighteen year olds learn a great deal about themselves while in college, but do not initially enroll with this as a goal, as much as do adult students. Even preparing for a career is a different task for traditional students, since it is their initial entry into the job market in most cases.

To summarize, many traditional students enroll in college in order to attain status as a college graduate, but do not seek the same level of selffulfillment that characterizes most adult learners. Also, while college is a life transition for young adults, going to school is not a result of a major life transition in the great majority of cases. 
Differences Between Traditional and Non-Traditional students

According to silling (1984) a number of differences between traditional-age and nontraditional adult students can be identified. Each of these differences influence teaching methods, evaluation techniques, and support services. Christensen (1980) describes twelve differences between traditional and non-traditional students. These differences are presented in Table 1. Christensen contends "Adult learners have a different perspective on life, a different sense of themselves and their time, what material is important to learn, and how they intend to use their education" (pp. 2329).

To summarize, the differences between traditional and non-traditional adult students can be categorized into three general factors:

Iife Experiences. Apps (1981) contends that because their age and experience, adult learners have a broader sense of how theoretical education relates to the world of work and society than do traditional students. Adults also bring to the classroom a wealth of background knowledge from 
Table 1

Characteristics of Traditional vs Non-Traditional students

Traditional student
Non-traditional student

\footnotetext{
1. Continuing in school

2. Learning history strongly influenced by formal education

3. Familiar with educational routine

4. Primary time commitment to school as full-time student

5. Adequate commuication and study skilis

6. Minimal work experience

7. Micro frame of reference for a more orderly input of new ideas
}

8. Frequently no clear vocational goal

9. Educational goal is to receive a baccalaureate degree at minimum

10. Speed of performance and peer competitiveness affects learning activities

11. High academic grades play significant role in obtaining meaningful employment

12. Clear idea of how he compares with academic performance of fellow students
1. Returning to school

2. Learning history strongly influenced by informal education

3. Unfamiliar with educational routine and expectations

4. Major time commitment to family and job: part-time student

5. Frequent deficiencies in study and communication skilis

6. Considerable relevant work experience

7. Macro frame of reference based on life experiences which has both positive and negative implications for learning process

8. Frequently clear vocational but not necessar1ly related to educational program

9. Educational goal may be to receive a degree, but may also include some form of licensure or certification

10. Concept mastery and accuracy of performance more immportant than competition frequently viewed as threatening.

11. Academic grades are not significant in terms of present employment situation

12. No accurate basis on which to judge his academic potential

Note. From "Traditional and adult students: A dichotomy," by D. R. Hameister, 1977, Lifelong Learning: The Adult Years, 4, p.8 
work or volunteer experiences. Part of the practical knowledge they have involves an ability to set goals, and prioritize and manage their time effectively. Adult learners tend to be more serious and committed to educational goals than are their younger counterparts, because of the relationship they see between education and selffulfillment in a variety of areas. Academic Behavior. Babcock (1982) reported that with the exception of math and the natural sciences, adult students' average grades are ten percent higher than those of traditional students.

Informal Learning. He further stated that adults become used to informal learning approaches while absent from school (e.g. TV, newspaper social activities). The return to formal learning, and academic roütines and regulations is often a difficult adjustment. Because of their various experiences adults are more likely to question the material being presented to them by instructors. They may need assistance to understand the relevance of the new learning to their own lives. 
Types of Problems Facing Adult Learners

Apps (1981) further reported that adult learners typically have a number of problems that may negatively impact on their educational experience without some intervention by counselors or attention from faculty members. For example, many adults who are undergoing a life transition have poor self-image and family problems. Those seeking immediate rewards in their career may come to college with unrealistic expectations and a excessively practical orientation. For others, many years out of school has resulted in diminished skills in writing mathematics, and study habits, making the initial adjustment to coursework a frustrating and sometimes negative experience.

Stalford (1978) identified three barriers facing adult students. Most adults in stalford's sample cited situational barriers as the most difficult to overcome. Situational barriers have to do with practical limitations which prospective and current students must overcome. Examples would include lack of money, transportation, and child care.

The second, dispositional barriers are selfimposed and psychological. For example, the lack of confidence of many adults in their own abilities leads 
to fear of failure, and fear of competing with younger students. Others must overcome guilt feelings they have about neglecting the family or spending part of the family income on education for themselves.

Stalford (1978) stated that the third barrier, institutional barriers can be the most frustrating for adult students because they have no control over them. Those barriers dramatically affect the adult student's ability to initially return to school or adjust once they have enrolled. For example, high tuition is a major institutional barrier for many adult students, especially because financial aid is not readily available to them. Practices and procedures such as inconvenient scheduling, poor selection of majors to choose from in evening or weekend programs, and inadequate student services for adults are other institutional barriers facing adult learners. Services Needed to Help Overcome Barriers Faced by Adult Learners

A number of services and programs can be implemented by colleges and universities to assist adult learners to overcome the barriers they face when returning to school. Using stalford's (1978) model of the three barriers, following is a summary description 
of student services used to overcome such barriers. overcoming Situational Barriers. Geisler and Thrush, (1975) cited lack of money as a major obstacle to continuing an education for many adults. Typically, adults take less than a full-time course load, making them ineligible for most forms of financial aid. Even if an adult does attend fulltime, the total family income is often too high for grants and loans especially since not all expenses are taken into consideration when eligibility is determined. Geisler and Thrush believe that to assist students to overcome this barrier, financial aid offices need to develop new sources of aid for adults and establish new criteria for eligibility (e.g. the expense for child care). In addition, institutions which continue to charge a higher tuition for parttime students are discriminating against the majority of older students who can only attend part-time. Cessation of this practice would assist adults to overcome the major problem of a lack of money.

Cross (1981) indicated that, women between the ages of 25 and 39 , many of whom have children younger than 18, currently make up the majority of adult students on campus. Many of them must make child care 
arrangements to enable them to take classes and find time to study. Convenient, low-cost, quality child care could be provided solely by the university, or in cooperation with community agencies.

Brandenburg (1974) cited that transportation is often a problem for returning adult students, particularly on those campuses that are not served by public transportation. For those without cars, transportation from the surrounding communities to campus needs to be convenient and timely. For those with cars parking should be convenient to classroom buildings, and either free or inexpensive. Well-lit parking lots and good security is also an important consideration for those adults taking evening classes. overcoming Dispositional Barriers. Geisler and Thrush (1975) included a variety of counseling interventions that can assist students to overcome dispositional barriers associated with returning to school. Initially, outreach programs for prospective students can extend recruitment and counseling services at community locations such as public libraries. The information provided in such "safe" environments may give them the confidence they need to enroll in coursework at a later time. 
According to Thrush (1975) once admitted these same students should be provided with a formal orientation, the primary purpose of which is to build confidence in themselves, and to reduce anxiety about their upcoming college experience. The orientation should include testing in mathematics and English to insure correct placement in these basic courses. A session on study skills is essential, as well as a tour of the campus. If possible, new adult students should have an opportunity to meet with faculty and other adult students in an informal atmosphere. An orientation of this type will assist adult students to develop positive perceptions of themselves as college students (Center for Research and Development in Higher Education (CRDHE, 1979).

Academic and career counseling should be available to adult students from the time of their initial enrollment until they complete the programs of their choice. New students need a great deal of assistance making course selections, setting academic goals, and determining the applicability of various degree programs to the job market. Working closely with an academic advisor at this point can help students develop confidence in their academic 
abilities and decision-making skills (Thrush, 1975). As adult students progress through their academic programs, career counseling becomes increasingly important. Career decisions must be made on the basis of reasonable expectations of employment with respect to age, sex, and job outlook in their home communities (Geisler and Thrush, 1975). By assimilating career counseling into the advising provided to adult students throughout their programs, they should experience fewer problems associated with unrealistic expectations of their education.

In order to increase employment opportunities available to adult students after graduation, career counselors need to become advocates for adult graduates.

Personal counseling can make the biggest difference to adult learners in their struggle to overcome dispositional barriers. Counselors who are sensitive to the special needs and problems of adults can help them deal with issues such as the lack of self-confidence, lack of a sense of personal direction, guilt over "neglecting" their families, resistance by family members to continue their education, and their own self-defeating thoughts and 
behaviors (Geisler \& Thrush, 1975).

other personal support services may also be important to adult students. Some institutions have a formal peer counseling program in which students who have experienced the same difficulties aid others to adjust to the collegial environment and lifestyle. Adult student organizations can also provide this same type of support and encouragement (Rawlins, 1981).

Personal counselors on college campuses are in a unique position to evaluate and influence the climate on campus with regard to adult students. Generalizations made from a number of adult student counseling sessions and research on the retention of adults can lead to changes in institutional policies, programs, and activities which may decrease the problems adults have in adjustment to college (Rawlins, 1981).

Overcoming Institutional Barriers. Resource Centers, or brokerage centers as they are sometimes called, are centralized offices on campuses which provide information to current and prospective students on educational and career opportunities, institutional policies and procedures, and other services available on campus and in the community. 
Some resource centers provide a variety of services during evening and weekend hours which are usually taken care of by other offices (e.g. tuition payment, registration, admissions). The staff in resource centers often act as advocates to help students cut through an institution's bureaucracy (Fauquet, 19.83).

Faculty attitudes toward adult students are often based on stereotypes. Geisler \& Thrush (1975) reported that women returning to school after several years of working in the home are often expected by faculty and staff to have lower career aspirations than traditional students. Because faculty are a key ingredient in providing a learning environment that is accepted and useful to returning students, they need to be trained to respect the special needs of adults and adapt some of their classroom techniques to them. Attitude training for faculty may help adult students feel more welcome in the classroom and on campus (Title \& Denker, 1980).

Admissions criteria at many institutions are the same for both traditional and non-traditional students. Outdated transcripts and standardized test scores that reflect rusty verbal and mathematics skills are not valid criteria for assessing the 
potential for success of an adult student. Using these methods also reinforces adults' fears and anxieties about returning to school. To overcome this obstacle, institutions need specialists to develop appropriate admissions criteria, evaluate past academic work, and assist adults through the bureaucracy associated with admission (Brandenberg, 1974).

To facilitate adult learners in their goal of meaningful learning experiences, colleges and universities must offer full evening and weekend educational programs for adults. Major changes in ways to earn credit, scheduling of classes, and teaching techniques are important if colleges and universities are to adapt to the special needs of adult students.

Encouragement to earn college credit through examinations, or by awarding credit for life experiences, would shorten the time required to earn a degree, reduce financial burdens, and give adult students a sense of accomplishment and recognition for their past personal achievements. Summary of the Review of the Iiterature The review of the literature presented a summary 
of pertinent studies on adult learning, and the needs of adult learners. Of particular importance was the summary of literature describing adult learning in higher education institutions (colleges and universities). This review emphasized the importance of three major barriers facing adult learners: Situational Barriers, which dealt with the practical limitations which prospective and current students must overcome. Examples would include lack of money, transportation and child care.

Dispositional Barriers, are self imposed and psychological barriers. For example, the lack of confidence of many adults leads to fear of failure and fear of competing with younger students.

Institutional Barriers, are the most frustrating for adult students since they have no control over them. High tuition is a major institutional barrier. Inconvenient scheduling and poor selection of majors are other institutional barriers facing adult students. The degree that colleges and universities are sensitive to adult learners, their needs, and the 
barriers confronting these learners will govern the level of programs and services designed and provided specifically to adult learners. This study examines the quality of student services being provided by five colleges and universities in Dade County, Florida, and their attempt to address these barriers.

The services identified in the literature, and to be examined in this study are the following:

1. Admissions information 10. Veterans Affairs

2. Convenient hours for 11. Study skills registration

12. Suitable study areas

3. Assistance in class

13. Access to library in registration evenings and weekends

4. Assistance in planning 14. Medical or health a class schedule care facilities

5. Orientation to campus 15. Participation in Iife campus activities

6. Academic counseling 16. Parking and security

7. Vocational career 17. Food services counseling 18. Bookstore

8. Personal counseling 19. Child care

9. Financial assistance 20. Access to computers While most colleges and universities provide a substantial number of these services to traditional 
51

students, their availability to adult learners is frequently limited. Further, the quality of the services provided to adult learners appears to be unequal to the services provided to traditional, full time students. It is the intent of this study to examine both the scope of student services available to adult learners and the quality of those available services. 
III. METHODOLOGY

This study examines the availability and quality of student services offered to adult learners in five colleges and universities in Dade County, Florida. This chapter describes the population of this study, the instruments.used in gathering the information considered essential for answering the six questions presented below, the data collection procedures, the Iimitations and analysis of the data.

The study is based on the six questions initially presented in Chapter I. They are listed as follows, followed with the measurements utilized in the questionnaire to determine the answer for each question.

1. What are the services being provided to adult learners by the five colleges and universities?

Data to answer this question were taken from the continuing Education student Services Questionnaire (CESSQ) (appendix A and $B)$, and discussed later in this chapter. Twenty services were listed, with the respondents requested to indicate their perception of the availability of each 
service. Percentages for all the responses were calculated and analyzed.

2. What is the quality of the services being provided as perceived by the administration? The administrators were also asked to give their perceptions of the quality of the services provided. These data were calculated and analyzed.

3. What is the quality of the services being provided as perceived by the adult learners? Similar to question 2 , the adult learners (students) were asked to indicate their perception of the 20 services listed. Percentages were calculated for all responses and the data analyzed.

4. Are there any differences in the services being provided to adult learners by the five colleges and universities?

The data collected to answer the first three questions were separated for each institution and similarly analyzed.

5. Are there any differences in the quality of the services as perceived by the administrators and adult learners? 
The data collected to answer the first three questions was further analyzed. Percentages were calculated and compared between the administrators and student respondents.

6. Are there any differences in the services provided to adult learners versus traditional college age students?

Similar to question five, the percentage of yes or no answers given by administrative respondents determined whether the delivery of the service was any different for adults than for traditional students.

Population

Two groups comprised the population for this study. One group included 107 adult learners (graduate or undergraduates) enrolled in credit courses being offered by the continuing education unit at each of the five colleges and universities in Dade County, Florida. The second group was the administrators of Admissions, Financial Aid, Registration, student services and Continuing Education Demographic and perceptual data were gathered by the CESSQ for both groups. 


\section{Instruments}

The Continuing Education student Service Questionnaire (CESSQ) the instrument designed to collect the required data, consists of two parts: eight demographic items and twenty items describing student services. The two instruments, one for administrators, and a similar one for adult learners, contained the same twenty items showing the types of student services which should be offered. Both are presented in the appendix (Appendix $A$ and $B$ ).

The two instruments were developed by the researcher in a pilot study; this study is described later in this chapter. The 20 items describing student services were based on a study by silling (1984) concerning services provided to adult learners. Data Collection

The data collection procedure consisted in administering the CESSQ to one credit class in the continuing education program at each institution. The administrator's questionnaire was completed by the five administrators from Admissions, Financial Aid, Registration, student services and continuing Education at each institution. All questionnaires to 
the adult learners and administrators were administered in person by the researcher.

Both questionnaires requested information on quality and importance of the student services. In addition the administrators were also asked about the delivery of services to adult learners versus traditional age students.

For response on quality of student services, a five point scale was developed $N=$ nonexistent, $1=$ poor quality, $2=$ moderate quality, $3=$ high quality and

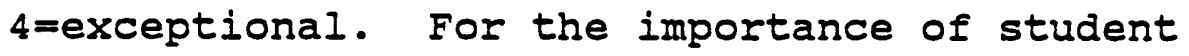
services, a four point scale was developed I=nonimportant, $2=$ fairly important, $3=$ very important and $4=e x t r e m e l y$ important. For the delivery of services, yes or no answers were utilized.

A Iimitation

one Iimitation of the study is that the results may not be generalizable beyond the five institutions in Dade County. Within each institution, a typical credit class was sampled, where typical indicates that the students enrolled in such class needed to use the student services listed in the questionnaire. Therefore, some generalization may be made to all credit classes offered by each institution. 
Applicability of the data to other institutions should not be made. Replication of the study, however, is encouraged. Analysis of the Data

For both the eight demographic variables and the twenty item questionnaire variables, percentages were calculated for each item. Tables listing the data and percentages were developed for each question. These are presented in the next chapter, the analysis of the data.

Pilot study

A pilot study was conducted to examine the needs of adult learners enrolled in a continuing education undergraduate credit class at Florida International University, and how those needs were being met by the faculty and staff. Permission was granted to administer a questionnaire to eight males and eight females participating in an off campus undergraduate credit class offered by the Division of Continuing Education. The questionnaire is presented in Appendix c. An interview was also conducted with the Dean of the Division. The interview instrument is presented in Appendix D. Appendix E provides a summary graph of the pilot study. Most of the students complained 
about the registration procedures, lack of courses available and access to the computer labs and the library.

The pilot study helped in identifying the target population, both in terms of administrators and students. It also helped in developing the instruments in this study, and clarifying the data to be acquired and analyzed. 
IV. PRESENTATION OF RESEARCH FINDINGS An analysis of the data collected during this investigation is presented in this chapter. Data were collected by means of the Continuing Education student Services Questionnaire (CESSQ). This instrument was used to determine the availability and quality of student services offered to adult learners enrolled in continuing education programs at selected universities in Dade County, Florida.

The Continuing Education student Services Questionnaire (CESSQ) consists of two parts: eight demographic items and twenty items describing student services. Two forms of the CESSQ were developed, one for administrators and one for adult learners. Both contained the same twenty items assessing the student services that are offered. The form for administrators had an additional question regarding the difference in the delivery of the services to adults and to traditional students. Both forms are presented in the Appendix ( $A$ and $B$ ).

The six research questions presented in Chapter 1 and 3 are the basis for the research on the CESSQ. The twenty items describing student services were based on a study by silling (1984) concerning services 
provided to adult learners.

The data from the questionnaires are presented in the following five sections: (1) a description of the adult learners and administrators participating in the study; (2) the adult learners' and administrators' perception of student services provided by universities; (3) the adult learners and administrators' perception of the quality of student services; (4) the administrators' perception of services provided to adult learners and traditional students; and (5) a comparison of the importance and availability of student services between adult learners and administrators. The data for each of these sections are presented in narrative and tabular form.

The Population of this study

The adult learner and administrator respondents in this study are described in this section. Collectively, they were 107 adult students attending, and 25 administrators working at five colleges and universities in Dade County, Florida. Permission to administer the CESSQ was requested from the Academic Dean and Dean of Continuing Education of each institution (see letter in Appendix $F$ and $G$ ). A copy 
of the CESSQ (Appendix B) was given to each instructor of the classes from which the adult students were surveyed, as well as to Deans of Continuing Education prior to its administration.

The colleges and universities in this study were: Florida International University (FIU), a state university with an enrollment of over 16,000; University of Miami (U.M), a private university with an enrollment of 10,000; Saint Thomas University (S.T.), a private church-related university with an enrollment of 2,500; Barry University (B.U.), another private university with an enrollment of 5,200; and Florida Memorial College (F.M.), a private, historically black college with an enrollment of 2,000 students. All five institutions have students affairs offices that provide a wide range of services for their students. The distribution of participants by institutions is presented in Table 2 .

The instruments were administered in person by the researcher to one continuing education credit class at each institution. The classes surveyed were selected by each institution's Dean of Continuing Education in consultation with the researcher. The criteria set by the researcher for selection required 
Table 2

Number of Participants in the study

\begin{tabular}{|c|c|c|c|c|c|c|c|}
\hline \multirow[b]{2}{*}{ Participants } & & \multicolumn{6}{|c|}{ Institutions } \\
\hline & & $\begin{array}{c}\text { F.I.U. } \\
N(z)\end{array}$ & $\begin{array}{l}\text { U.M. } \\
N(z)\end{array}$ & $\begin{array}{l}S . T . \\
N(z)\end{array}$ & $\begin{array}{l}\text { F.M. } \\
N(z)\end{array}$ & $\begin{array}{l}\text { B.U. } \\
N(z)\end{array}$ & $\begin{array}{c}\text { Total } \\
N(z)\end{array}$ \\
\hline Adult Learners & & $23(218)$ & $16(158)$ & $20(198)$ & $21(208)$ & $27(258)$ & $107(1008)$ \\
\hline Administrators & & $5(218)$ & $5(208)$ & $5(208)$ & $5(208)$ & $5(20 z)$ & $25(1008)$ \\
\hline Totals & & $28(218)$ & $21(16 \%)$ & $25(198)$ & $26(208)$ & $32(248)$ & $132(1008)$ \\
\hline \multicolumn{8}{|l|}{ a Institutions: } \\
\hline F.I.U. & - & \multicolumn{6}{|c|}{ Florida International University } \\
\hline U.M. & - & \multicolumn{6}{|c|}{ University of Miami } \\
\hline S.T. & - & \multicolumn{6}{|c|}{ saint Thomas University } \\
\hline F.M. & - & \multicolumn{6}{|c|}{ Florlda Memorial College } \\
\hline B.U. & - & \multicolumn{6}{|c|}{ Barry University } \\
\hline
\end{tabular}

the classes be degree credit classes with a minimum of fifteen adult learners, and a diverse representation of sex, race and major areas of study.

The instrument for the administrators was completed by five administrators at each institution: the directors (or a similar title) of admissions, financial aid, registration, student services and continuing education.

Adult Learner Respondents. Table 3 presents the biographical data of the adult learners. Three demographic characteristics were derived from the eight questions in 
Table 3

Biographical Data of Adult Learners

\begin{tabular}{|c|c|c|c|c|c|c|}
\hline \multirow{4}{*}{ Total } & \multicolumn{6}{|c|}{ Institutions } \\
\hline & \multirow{2}{*}{$\begin{array}{c}\text { F.I.U. } \\
23\end{array}$} & \multirow{2}{*}{$\begin{array}{c}\text { U.M. } \\
16\end{array}$} & \multirow{2}{*}{$\begin{array}{l}\text { S.T. } \\
20\end{array}$} & \multirow{2}{*}{$\begin{array}{c}\text { F.M. } \\
21\end{array}$} & \multirow{2}{*}{$\begin{array}{c}\text { B.U. } \\
27 .\end{array}$} & \multirow{2}{*}{$\begin{array}{c}\text { Total } \\
107\end{array}$} \\
\hline & & & & & & \\
\hline & $N(z)$ & $N(z)$ & $N(z)$ & $N(z)$ & $N(z)$ & $N(z)$ \\
\hline \multicolumn{7}{|l|}{$\operatorname{sex}$} \\
\hline Male & $0(08)$ & $13(818)$ & $2(108)$ & $10(478)$ & $9(33 \%)$ & $34(318)$ \\
\hline Female & $23(1008)$ & $3(188)$ & $18(908)$ & $11(528)$ & $18(668)$ & $73(688)$ \\
\hline \multicolumn{7}{|l|}{ Age } \\
\hline Average $(\bar{x})$ & 24.6 & 33.5 & 29.5 & 24.4 & 32.2 & 28.9 \\
\hline Range & $20-48$ & $22-47$ & $21-56$ & $19-40$ & $21-58$ & $19-58$ \\
\hline \multicolumn{7}{|c|}{ Marital Status } \\
\hline single & $15(658)$ & $6(378)$ & $10(528)$ & $17(85 \%)$ & $11(408)$ & $59(568)$ \\
\hline Married & $7(308)$ & $7(438)$ & $7(368)$ & $1(5 \%)$ & $12(448)$ & $34(32 \%)$ \\
\hline Divorced & $1(48)$ & $3(188)$ & $1(108)$ & $2(108)$ & $4(148)$ & $12(118)$ \\
\hline \multicolumn{7}{|c|}{ Native Language } \\
\hline English & $13(568)$ & $12(758)$ & $8(408)$ & $18(908)$ & $17(638)$ & $68(65 \%)$ \\
\hline Spanish & $10(448)$ & $5(258)$ & $12(608)$ & $0(08)$ & $7(268)$ & $33(328)$ \\
\hline French & $0(0 \&)$ & $0(08)$ & $0(08)$ & $1(58)$ & $1(48)$ & $2(18)$ \\
\hline other & $O(0 z)$ & $O(08)$ & $0(08)$ & $1(58)$ & $2(78)$ & $3(28)$ \\
\hline \multicolumn{7}{|c|}{ Educational Level } \\
\hline H.S.Grad. & $1(48)$ & $0(08)$ & $1(58)$ & $4(20 \%)$ & $1(48)$ & $7(68)$ \\
\hline 2 Yrs. Coll. & $11(488)$ & $4(258)$ & $9(458)$ & $14(708)$ & $12(528)$ & $50(498)$ \\
\hline coll.Grad. & $10(448)$ & $9(578)$ & $9(458)$ & $2(108)$ & $10(448)$ & $40(398)$ \\
\hline Grad.Sch. & $1(48)$ & $3(188)$ & $1(58)$ & $0(08)$ & $0(08)$ & $5(48)$ \\
\hline \multicolumn{7}{|l|}{ Income Level } \\
\hline $0-\$ 10,000$ & $16(768)$ & $0(98)$ & $5(258)$ & $10(508)$ & $2(78)$ & $33(328)$ \\
\hline $11-\$ 20,000$ & $2(98)$ & $1(68)$ & $8(40 \%)$ & $9(4589)$ & $10(378)$ & $30(298)$ \\
\hline $21-\$ 35,000$ & $2(98)$ & $5(338)$ & $4(208)$ & $1(58)$ & $11(408)$ & $23(22 \%)$ \\
\hline $36-\$ 50,000$ & $1(48)$ & $5(33 \%)$ & $3(158)$ & $0(08)$ & $2(78)$ & $11(108)$ \\
\hline$\$ 50,000+$ & $0(08)$ & $4(268)$ & $0 .(0 \%)$ & $0(08)$ & $2(78)$ & $6(58)$ \\
\hline
\end{tabular}


the first part of the CESSQ.

Thirty-four (31\%) of the adult learner

respondents were male, while 73 (68\%) were female. The mean age was 28.87 years with a range of $18-58$ years old.

Regarding other demographic characteristics of the respondents, 34 (32\%) were married and 12 (11\%) were divorced. Sixty-eight students (64\%) indicated English as their native language, 35 (31\%) indicated Spanish, and two ( $1 \%$ ) indicated French as their native tongue.

The educational level of the adult learners varied widely with seven students (6\%) being high school graduates, 50 students (49\%) finishing two years of college, 50 (39\%) having a bachelor's degree, and five ( $4 \%$ ) having some type of graduate experience.

The income level ranged from 33 students (32\%) earning below $\$ 10,000$ per year to six students (5\%) earning over $\$ 50,000$ per year. The average annual income for all 107 students was between $\$ 15,000$ and $\$ 21,000$.

In summary, the average or typical adult learner surveyed in this study was a female, 28 years old, single, of English speaking background, completed two 
years of college, and an income of $\$ 10,000$ per year. This profile is supported by Apps (1981), who identified the adult learner in higher education as predominantly female, white, between the ages of 25 and 39 , and from urban or suburban areas.

Although Dade County has a significant number of hispanics, they constituted less than half of the adult learners surveyed in this study.

Administrators Respondents. The administrators in the study consisted of five persons from each institution responsible for admissions, financial aid, registration, student services and continuing education. The demographic characteristics of the administrators are presented in Table 4.

Two ( $8 \%$ ) administrators were males, while 23 (92\%) administrators were females. The mean age for both genders was 41.7 years, with a range between 25 and 60 years of age. Two administrators did not respond to the age question.

Seven (28\%) of the administrators were single, 15 (50\%) were married, and three (12\%) were divorced. Eighteen administrators (72\%) reported English as their native language while five (20\%) indicated Spanish and one (4\%) responded as "other" being 
Table 4

Blographical Data of Administrators

Inst 1tutions

$\begin{array}{rrrrrrr} & \text { F.I.U. } & \text { U.M. } & \text { S.T. } & \text { F.M. } & \text { B.U. } & \text { Total } \\ \text { Total } & 5 & 5 & 5 & 5 & 5 & 25 \\ & \text { N }(z) & \text { N (z) } & \text { N }(z) & \text { N (z) } & \text { N(z) } & \text { N (z) }\end{array}$

$\operatorname{sex}$

Male o( 08) $1(208) \quad 1(208)$ o( 08$)$ of 08$) \quad 2(88$ Female $5(1008) \quad 4(808) \quad 4(808) \quad 5(1008) \quad 5(1008) \quad 23(928$

Age

$\begin{array}{lllllll}\text { Average }(\bar{x}) & 41.4 & 42.6 & 50.8 & 41.0 & 32.8 & 41.7\end{array}$

Marital status

single $\quad 1(208) \quad 0(08) \quad 1(208) \quad 3(608) \quad 2(408) \quad 7(288)$

$\begin{array}{llllll}\text { Marrled } \quad 4(808) \quad 4(808) \quad 2(408) \quad 2(408) \quad 3(608) & 15(608)\end{array}$

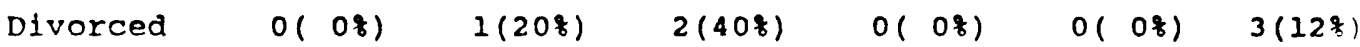

Native Language

$\begin{array}{lllllll}\text { English } & 3(608) & 4(808) & 3(608) & 4(808) & 4(808) & 18(758)\end{array}$

Spanish $1(208) \quad 1(208) \quad 2(408) \quad 1(208) \quad 1(208) \quad 5(218)$

French $0(08) \quad 0(08) \quad 0(08) \quad 0(08) \quad 0(08) \quad 0(08$ )

other $1(208) \quad 0(08) \quad 0(08) \quad 0(08) \quad 0(08) \quad 1(48)$

Educational Level

2 Yrs.coll. O( 08$) \quad O(08) \quad 0(08) \quad 1(208) \quad 0(08) \quad 1(48)$

coll.Grad. $1(208) \quad 2(208) \quad 2(408) \quad 2(408) \quad 2(408) \quad 8(318)$

Grad.Sch. $\quad 4(80 z) \quad 4(808) \quad 3(608) \quad 2(408) \quad 3(608) \quad 16(658)$

Income Level

$10-\$ 20,000 \quad 0(08) \quad 0(08) \quad 1(208) \quad 1(208) \quad 1(208) \quad 3(128)$

$20-\$ 25,000 \quad 4(808) \quad 2(408) \quad 3(608) \quad 3(608) \quad 3(608) \quad 16(648)$

$35-\$ 50,000 \quad 1(208) \quad 2(408) \quad 0(08) \quad 1(208) \quad 1(208) \quad 5(208)$

$\$ 50,000+0(08) \quad 1(208) \quad 0(08) \quad 0(08) \quad 0(08) \quad 1(48)$ 
his/her native tongue.

The administrators' educational level shows that one ( $4 \%$ ) had two years of college, eight (32\%) were college graduates while 17 (68\%) had some graduate experience.

The income level ranged from three (12\%) reporting incomes between $\$ 10,000$ and $\$ 20,000$ per year, $16(64 \%)$ between $\$ 21,000$ and $\$ 35,000$, five (20\%) between $\$ 36,000$ and $\$ 50,000$ and one $(4 \%)$ reported earnings over $\$ 50,000$ per year. The average income for administrators was between $\$ 25,000$ and $\$ 30,000$ per year.

In summary, the average or typical administrator surveyed in this study was a female, 41 years old, married, of English speaking background, having completed a graduate degree and with an annual income between $\$ 20,000$ and $\$ 25,000$.

Adult Learners' and Administrators' Perceptions of Student Services being Provided.

The remaining sections of this chapter presents the data from the survey that examines the six research questions of this study. These questions were examined within the framework of the three barriers facing adult students as identified by 
Stalford (1978) in Chapter II. The first barrier was situational, having to do with practical limitations which prospective and current students must overcome. Examples would include lack of money, transportation and child care. Some of the services meeting such needs are: financial aid assistance and counseling, child care, parking and security and veterans affairs counseling.

The second barrier was dispositional, self imposed and psychological, for example the lack of confidence of many adults in their own abilities lead to fear of failure, and fear of competing with younger students. Some of the services addressing such barriers are: orientation to campus life, admissions information, study skills assistance, academic counseling, personal counseling, etc.

The third barrier, institutional barrier, can be the most frustrating, since adult students may have no control over them. Examples of institutional barriers are: high tuition, inconvenient scheduling, poor selection of majors, etc. Some of the services geared to meet such needs are assistance in class registration, financial aid, access to library in evening and weekends, assistance in planning a class 
schedule, etc.

The first and fourth questions examined in this study were "What are the services being provided to adult learners by the five colleges and universities?" and "Are there any differences in the services being provided to adult learners by the five colleges and universities?"

Table five presents the responses of the adult learners' perception of the availability of 20 services at the five institutions, table six presents the administrators' perception. The responses are ranked in order of the availability of services. Both tables show the percentages of adult learners and administrators indicating the services provided by each institution.

Adult Learners' Perceptions of student Services. The data does not show any major difference in the services provided to adult learners by all five colleges and universities. That is, all five provide convenient hours for registration, assistance in class registration, bookstore services, admission information and access to computers. This can be attributable to the common location shared by the five institutions and the similarity of their student 
Table 5

Percentage of Adult Learners Indicating student Services Provided by

\section{Institutions}

Institutions

F.I.U. U.M. S.T. F.M. B.U. Total

Total

$\begin{array}{llllll}23 & 16 & 20 & 21 & 27 & 107\end{array}$

$N(\xi) \quad N(z) \quad N(z) \quad N(z) \quad N(z) \quad$ Average

\begin{tabular}{|c|c|c|c|c|c|c|c|}
\hline 1. & $\begin{array}{l}\text { Convenient hours for } \\
\text { registration }\end{array}$ & $\begin{array}{l}.23 \\
(1008)\end{array}$ & $\begin{array}{c}16 \\
(1008)\end{array}$ & $\begin{array}{l}20 \\
(95 \%)\end{array}$ & $\begin{array}{l}20 \\
(1008)\end{array}$ & $\begin{array}{l}26 \\
(968)\end{array}$ & $\begin{array}{l}105 \\
(99 \%)\end{array}$ \\
\hline 2 . & $\begin{array}{l}\text { Assistance in class } \\
\text { registration }\end{array}$ & $\begin{array}{l}23 \\
(1008)\end{array}$ & $\begin{array}{c}16 \\
(100 \%)\end{array}$ & $\begin{array}{l}18 \\
(85 \%)\end{array}$ & $\begin{array}{l}19 \\
(95 \%)\end{array}$ & $\begin{array}{l}27 \\
(1008)\end{array}$ & $\begin{array}{l}103 \\
(998)\end{array}$ \\
\hline 3. & $\begin{array}{l}\text { Assistance in planning a } \\
\text { class schedule }\end{array}$ & $\begin{array}{l}22 \\
(96 \%)\end{array}$ & $\begin{array}{c}12 \\
(75 \%)\end{array}$ & $\begin{array}{c}20 \\
(95 \%)\end{array}$ & $\begin{array}{c}20 \\
(1008)\end{array}$ & $\begin{array}{c}26 \\
(96 \%)\end{array}$ & $\begin{array}{l}100 \\
(998)\end{array}$ \\
\hline 4. & Bookstore & $\begin{array}{l}21 \\
(91 \%)\end{array}$ & $\begin{array}{c}13 \\
(81 \%)\end{array}$ & $\begin{array}{c}21 \\
(1008)\end{array}$ & $\begin{array}{c}20 \\
(1008)\end{array}$ & $\begin{array}{c}26 \\
(96 \%)\end{array}$ & $\begin{array}{l}101 \\
(998)\end{array}$ \\
\hline 5. & Admission information & $\begin{array}{c}22 \\
(968)\end{array}$ & $\begin{array}{c}16 \\
(1008)\end{array}$ & $\begin{array}{c}20 \\
(100 \%)\end{array}$ & $\begin{array}{c}20 \\
(100 \%)\end{array}$ & $\begin{array}{c}26 \\
(968)\end{array}$ & $\begin{array}{l}105 \\
(988)\end{array}$ \\
\hline 6. & Access to computers & $\begin{array}{c}23 \\
(1008)\end{array}$ & $\begin{array}{c}14 \\
(87 \&)\end{array}$ & $\begin{array}{c}21 \\
(1008)\end{array}$ & $\begin{array}{c}20 \\
(100 \%)\end{array}$ & $\begin{array}{c}25 \\
(92 \%)\end{array}$ & $\begin{array}{l}103 \\
(98 \%)\end{array}$ \\
\hline 7. & Parking and security & $\begin{array}{c}23 \\
(100 \%)\end{array}$ & $\begin{array}{c}15 \\
(93 \%)\end{array}$ & $\begin{array}{c}20 \\
(95 \%)\end{array}$ & $\begin{array}{c}17 \\
(85 \%)\end{array}$ & $\begin{array}{c}26 \\
(96 \%)\end{array}$ & $\begin{array}{l}101 \\
(97 \%)\end{array}$ \\
\hline $8:$ & Academic counseling & $\begin{array}{l}22 \\
(96 \%)\end{array}$ & $\begin{array}{c}7 \\
(43 \%)\end{array}$ & $\begin{array}{c}20 \\
(95 \%)\end{array}$ & $\begin{array}{c}18 \\
(90 \%)\end{array}$ & $\begin{array}{c}36 \\
(96 \%)\end{array}$ & $\begin{array}{c}93 \\
(948)\end{array}$ \\
\hline 9. & $\begin{array}{l}\text { Financial Aid assistance } \\
\text { and counseling }\end{array}$ & $\begin{array}{l}21 \\
(918)\end{array}$ & $\begin{array}{c}7 \\
(43 \%)\end{array}$ & $\begin{array}{l}20 \\
(958)\end{array}$ & $\begin{array}{l}19 \\
(95 \%)\end{array}$ & $\begin{array}{l}24 \\
(88 \%)\end{array}$ & $\begin{array}{l}91 \\
(93 \%)\end{array}$ \\
\hline 10. & Food Services & $\begin{array}{l}23 \\
(1008)\end{array}$ & $\begin{array}{c}9 \\
(56 \%)\end{array}$ & $\begin{array}{l}17 \\
(80 \%)\end{array}$ & $\begin{array}{l}12 \\
(60 \%)\end{array}$ & $\begin{array}{l}25 \\
(92 \%)\end{array}$ & $\begin{array}{l}86 \\
(89 \%)\end{array}$ \\
\hline 11. & $\begin{array}{l}\text { Participation in campus } \\
\text { activities }\end{array}$ & $\begin{array}{l}21 \\
(91 \%)\end{array}$ & $\begin{array}{c}8 \\
(50 \%)\end{array}$ & $\begin{array}{l}18 \\
(85 \%)\end{array}$ & $\begin{array}{l}14 \\
(708)\end{array}$ & $\begin{array}{l}15 \\
(55 \%)\end{array}$ & $\begin{array}{l}76 \\
(87 \%)\end{array}$ \\
\hline 12. & $\begin{array}{l}\text { orientation to campus } \\
\text { Iife }\end{array}$ & $\begin{array}{l}19 \\
(828)\end{array}$ & $\begin{array}{c}8 \\
(50 \%)\end{array}$ & $\begin{array}{l}18 \\
(85 \%)\end{array}$ & $\begin{array}{l}14 \\
(75 \%)\end{array}$ & 15 & $\begin{array}{l}76 \\
(87 \%)\end{array}$ \\
\hline
\end{tabular}




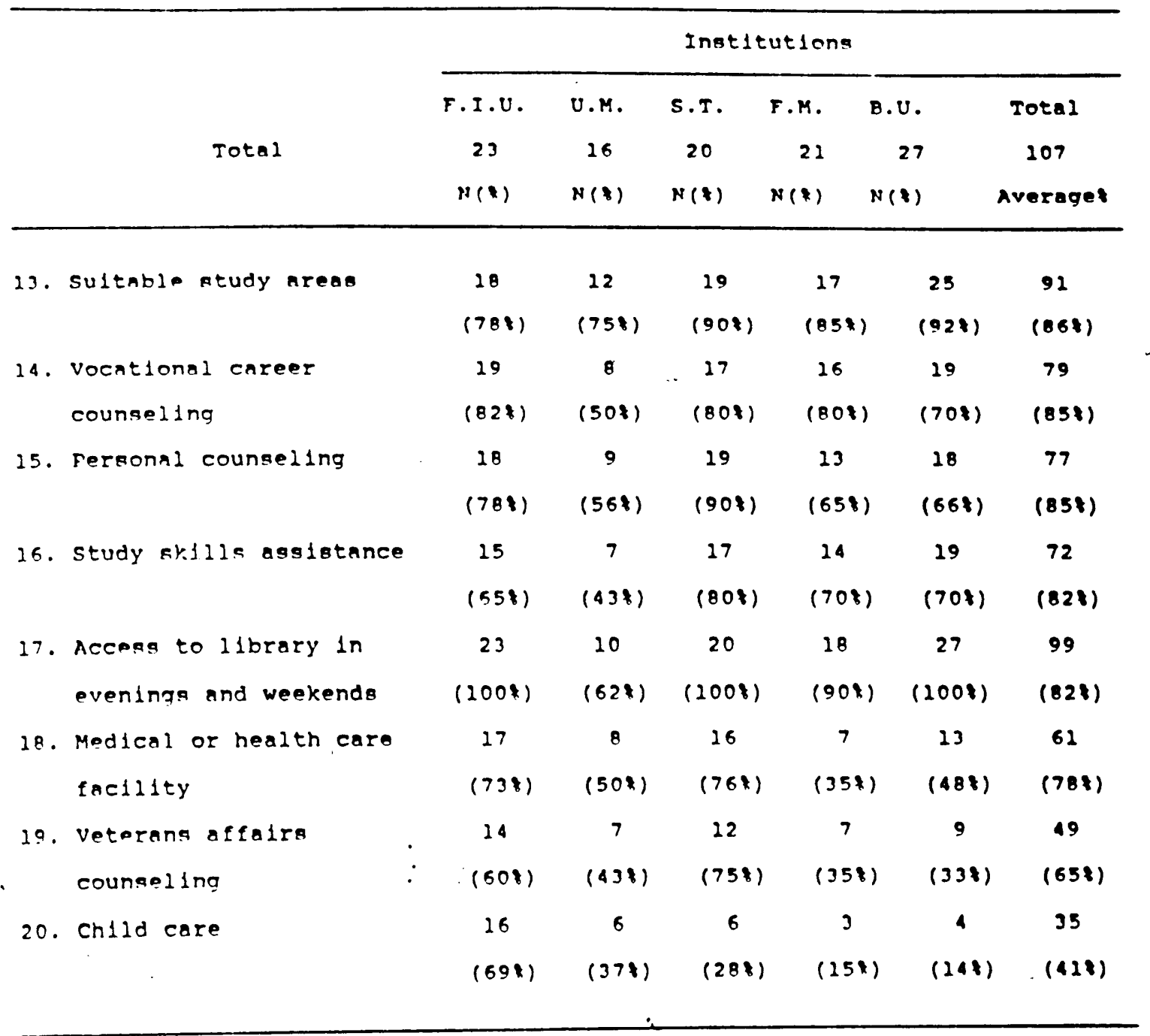

bodies. However, it was the researcher's perception that the two largest universities, one private and one public, offered the best facilities (classroom space, building conveniences) for adult learners although not necessarily the best services.

At all five institutions, the five services most available to adult learners as perceived by the adult 
Percentage of Administrators Indicating Student Services Provided by

\begin{tabular}{|c|c|c|c|c|c|c|c|}
\hline \multirow{2}{*}{\multicolumn{2}{|c|}{ Total }} & \multicolumn{6}{|c|}{ Institutions } \\
\hline & & $\begin{array}{c}\text { F.I.U. } \\
5 \\
N(\xi)\end{array}$ & $\begin{array}{c}U . M . \\
5 \\
N(8)\end{array}$ & $\begin{array}{c}\text { S.T. } \\
5 \\
N(\&)\end{array}$ & $\begin{array}{c}F \cdot M . \\
5 \\
N(z)\end{array}$ & $\begin{array}{c}\text { B.U. } \\
5 \\
N(z)\end{array}$ & $\begin{array}{c}\text { Total } \\
25 \\
\text { Averaget }\end{array}$ \\
\hline 1 & Admissions Information & $\begin{array}{c}5 \\
(1008)\end{array}$ & $\begin{array}{c}5 \\
(1008)\end{array}$ & $\begin{array}{c}5 \\
(1008)\end{array}$ & $\begin{array}{c}5 \\
(1008)\end{array}$ & $\begin{array}{c}5 \\
(1008)\end{array}$ & $\begin{array}{c}25 \\
(1008)\end{array}$ \\
\hline 2 . & $\begin{array}{l}\text { Convenient hours for } \\
\text { registration }\end{array}$ & $\begin{array}{c}5 \\
(1008)\end{array}$ & $\begin{array}{c}5 \\
(1008)\end{array}$ & $\begin{array}{c}5 \\
(1008)\end{array}$ & $\begin{array}{c}5 \\
(1008)\end{array}$ & $\begin{array}{c}5 \\
(100 \%)\end{array}$ & $\begin{array}{c}25 \\
(100 \%)\end{array}$ \\
\hline 3. & $\begin{array}{l}\text { Assistance in class } \\
\text { registration }\end{array}$ & $\begin{array}{c}5 \\
(100 \%)\end{array}$ & $\begin{array}{c}5 \\
(1008)\end{array}$ & $\begin{array}{c}5 \\
(1008)\end{array}$ & $\begin{array}{c}5 \\
(1008)\end{array}$ & $\begin{array}{c}5 \\
(1008)\end{array}$ & $\begin{array}{c}25 \\
(100 \%)\end{array}$ \\
\hline 4 & study skills assistance & $\begin{array}{c}5 \\
(1008)\end{array}$ & $\begin{array}{c}5 \\
(1008)\end{array}$ & $\begin{array}{c}5 \\
(100 \%)\end{array}$ & $\begin{array}{c}5 \\
(1008)\end{array}$ & $\begin{array}{c}5 \\
(1008)\end{array}$ & $\begin{array}{c}25 \\
(1008)\end{array}$ \\
\hline 5 & $\begin{array}{l}\text { Access to library in } \\
\text { evenings and weekends }\end{array}$ & $\begin{array}{c}5 \\
(1008)\end{array}$ & $\begin{array}{c}5 \\
(100 q)\end{array}$ & $\begin{array}{c}5 \\
(1008)\end{array}$ & $\begin{array}{c}5 \\
(1008)\end{array}$ & $\begin{array}{c}5 \\
(100 \%)\end{array}$ & $\begin{array}{c}25 \\
(1008)\end{array}$ \\
\hline 6. & $\begin{array}{l}\text { Financial Aid assistance } \\
\text { and counseling }\end{array}$ & $\begin{array}{c}5 \\
(100 \%)\end{array}$ & $\begin{array}{c}5 \\
(1008)\end{array}$ & $\begin{array}{c}4 \\
(80 q)\end{array}$ & $\begin{array}{c}5 \\
(1008)\end{array}$ & $\begin{array}{c}5 \\
(100 \%)\end{array}$ & $\begin{array}{l}24 \\
(968)\end{array}$ \\
\hline 7 . & $\begin{array}{l}\text { Participation in campus } \\
\text { activities }\end{array}$ & $\begin{array}{c}5 \\
(1008)\end{array}$ & $\begin{array}{c}5 \\
(1008)\end{array}$ & $\begin{array}{c}5 \\
(1008)\end{array}$ & $\begin{array}{c}4 \\
(80 \%)\end{array}$ & $\begin{array}{c}5 \\
(1008)\end{array}$ & $\begin{array}{l}24 \\
(96 \%)\end{array}$ \\
\hline 8: & $\begin{array}{l}\text { Assistance in planning } \\
\text { a class schedule }\end{array}$ & $\begin{array}{c}4 \\
(80 \%)\end{array}$ & $\begin{array}{c}5 \\
(1008)\end{array}$ & $\begin{array}{c}5 \\
(1008)\end{array}$ & $\begin{array}{c}5 \\
(100 \%)\end{array}$ & $\begin{array}{c}4 \\
(80 \%)\end{array}$ & $\begin{array}{l}23 \\
(928)\end{array}$ \\
\hline 9. & $\begin{array}{l}\text { orientation to campus } \\
\text { Iife }\end{array}$ & $\begin{array}{c}5 \\
(1008)\end{array}$ & $\begin{array}{c}5 \\
(100 \%)\end{array}$ & $\begin{array}{c}4 \\
(808)\end{array}$ & $\begin{array}{c}5 \\
(1008)\end{array}$ & $\begin{array}{c}4 \\
(808)\end{array}$ & $\begin{array}{l}23 \\
(92 \%)\end{array}$ \\
\hline 10 & Academic counseling & $\begin{array}{c}4 \\
(80 \%)\end{array}$ & $\begin{array}{c}5 \\
(100 \%)\end{array}$ & $\begin{array}{c}4 \\
(80 \%)\end{array}$ & $\begin{array}{c}5 \\
(1008)\end{array}$ & $\begin{array}{c}5 \\
(1008)\end{array}$ & $\begin{array}{l}23 \\
(92 \%)\end{array}$ \\
\hline 11. & $\begin{array}{l}\text { Medical or health care } \\
\text { facility }\end{array}$ & $\begin{array}{c}5 \\
(1008)\end{array}$ & $\begin{array}{c}5 \\
(1008)\end{array}$ & $\begin{array}{c}3 \\
(60 \%)\end{array}$ & $\begin{array}{c}4 \\
(80 \%)\end{array}$ & $\begin{array}{c}5 \\
(1008)\end{array}$ & $\begin{array}{l}22 \\
(888)\end{array}$ \\
\hline 12. & Parking and security & $\begin{array}{c}5 \\
(100 \%)\end{array}$ & $\begin{array}{c}4 \\
(808)\end{array}$ & $\begin{array}{c}3 \\
(60 \%)\end{array}$ & $\begin{array}{c}5 \\
(100 \%)\end{array}$ & $\begin{array}{c}5 \\
(1008)\end{array}$ & $\begin{array}{c}22 \\
(88 \%)\end{array}$ \\
\hline
\end{tabular}




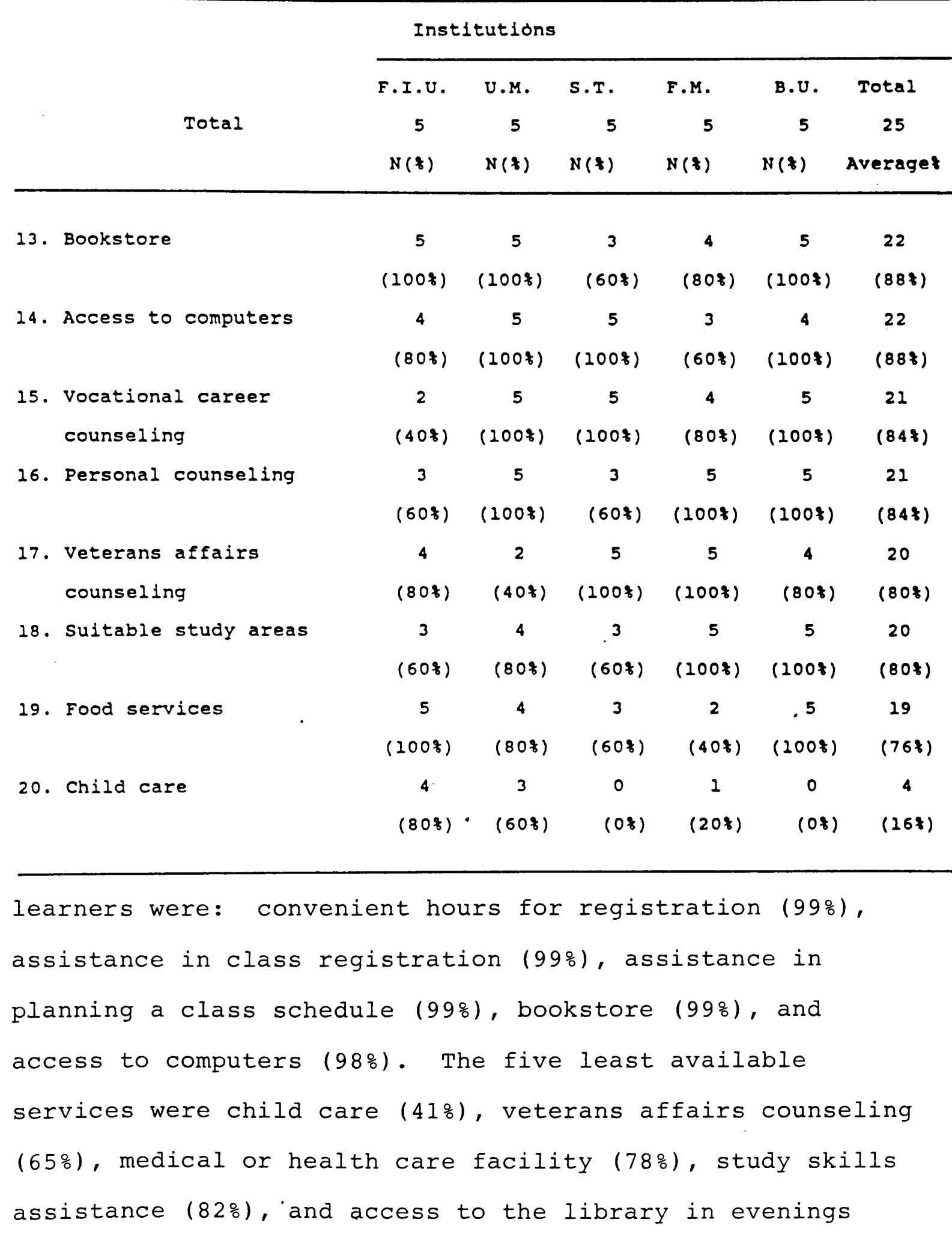


and weekends $(82 \%)$.

The nine services receiving a $100 \%$ response at one or more institutions were: admissions information (three institutions), convenient hours for registration (three institutions), assistance in class registration (three institutions), assistance in planning a schedule (one institution), access to library in evenings and weekends (three institutions), parking and security (one institution), food services (one institution), bookstore (two institutions) and access to computers (three institutions).

It should be noted that adult learners in three of the private universities reported a $100 \%$ availability of admission information, while the adult learners at the public university reported $96 \%$ availability. Only two of the small private institutions reported $95 \%$ and $96 \%$ respectively in availability of convenient hours for registration, while the remaining three reported $100 \%$ availability. Administrators' Perceptions of student services. Table 6 presents the percentage of administrators indicating the availability of services at their respective institutions. The five most available services listed by the administrators respondents 
were: admissions information (100\%), convenient hours for registration (100\%), assistance in class registration (100\%), study skills assistance (100\%) and access to library in evenings and weekends (100\%). The least available services according to administrators' responses were: child care (16\%), suitable study areas ( $80 \%)$, personal counseling ( $84 \%$ ), vocational career counseling $(84 \%)$, medical or health care facility (88\%) and parking and security ( $88 \%)$. The data show agreement of administrators and students on the following services being provided: admissions information, convenient hours for registration, assistance in class registration, assistance in planning a class schedule, orientation to campus life, academic counseling and financial aid assistance and counseling. Also, both adult learners and administrators agree on the poor availability of child care (16\% administrators versus $41 \%$ adult learners). The data further show that, in the following areas a lower percentage of administrators, but a higher percentage for adult learners, indicated the service was provided: bookstore (administrators $88 \%$ versus adult learners $99 \%$ ), access to computers ( $88 \%$ versus $98 \%$ ), parking and security ( $88 \%$ versus 
$97 \%$ ) and food services (76\% versus $89 \%$ ) respectively. The areas where a high percentage of administrators indicated the service was provided but a lower percentage of adult learners concurred were: study skills assistance (administrators 100\% versus adult learners $82 \%$ ), access to library in evenings and weekends ( $100 \%$ versus $82 \%$ ), medical or health care facility ( $88 \%$ versus $78 \%$ ) and veterans affairs counseling ( $80 \%$ versus $65 \%$ ). Adult Learners' and Administrators' Perceptions of Quality of student services

The second, third and fifth of the six research questions for the study were: "What is the quality of the services being provided as perceived by the administrators?"; "What is the quality of the services provided as perceived by the adult learner?"; and "Are there any differences in the quality of the services as perceived by the administrators and adult learners?" Table 7 presents the percentage of administrators and adult learners indicating low quality versus high quality for student services. The services are ranked in decreasing order of percentage of low quality as indicated by adult learners.

To categorize the perception of the quality of 
Table 7

Fercentage of Administrators' and Adult Learnera. Perception of the

Quality of the student services Provided by the Inst1tutions

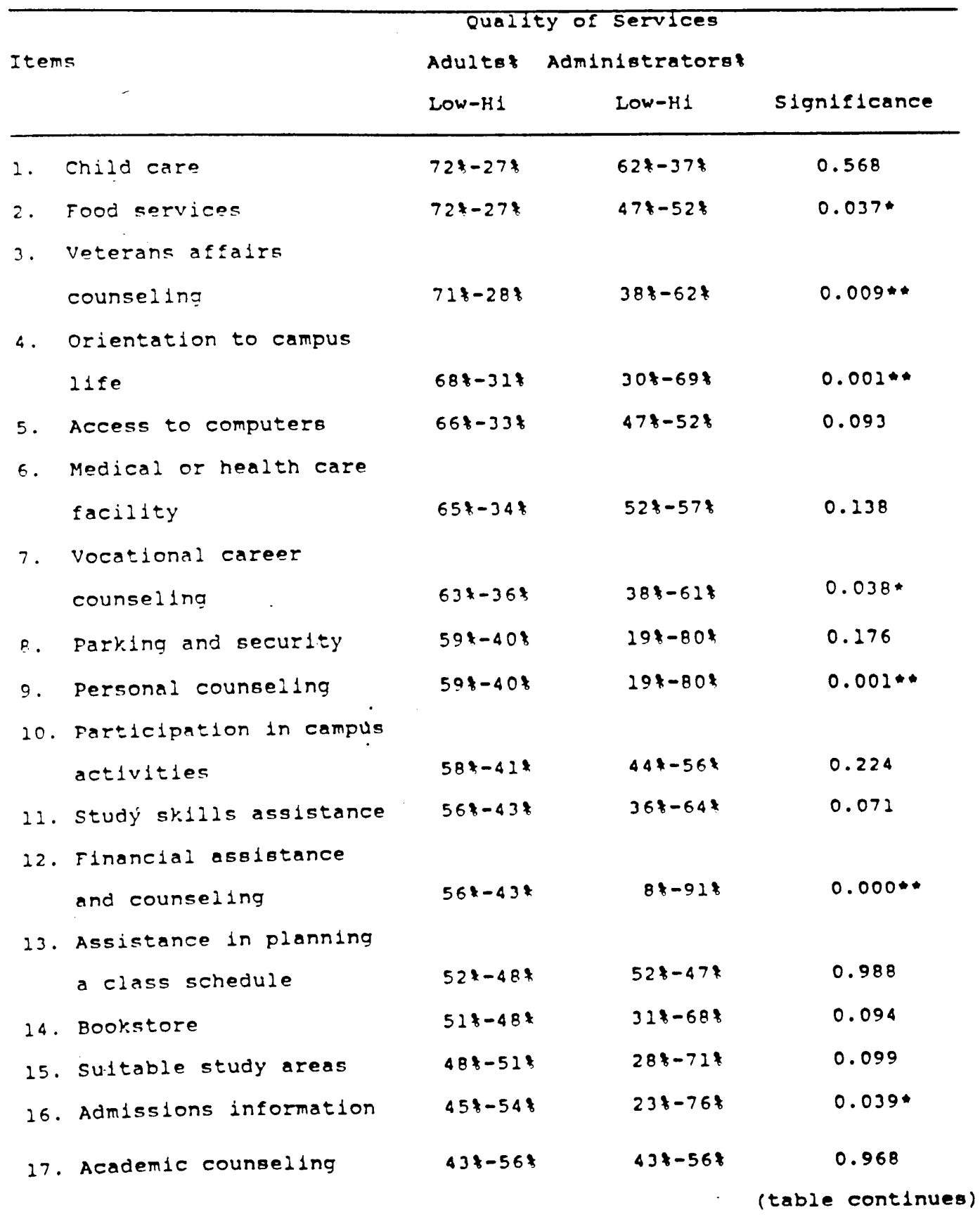


(Table 7 continued)

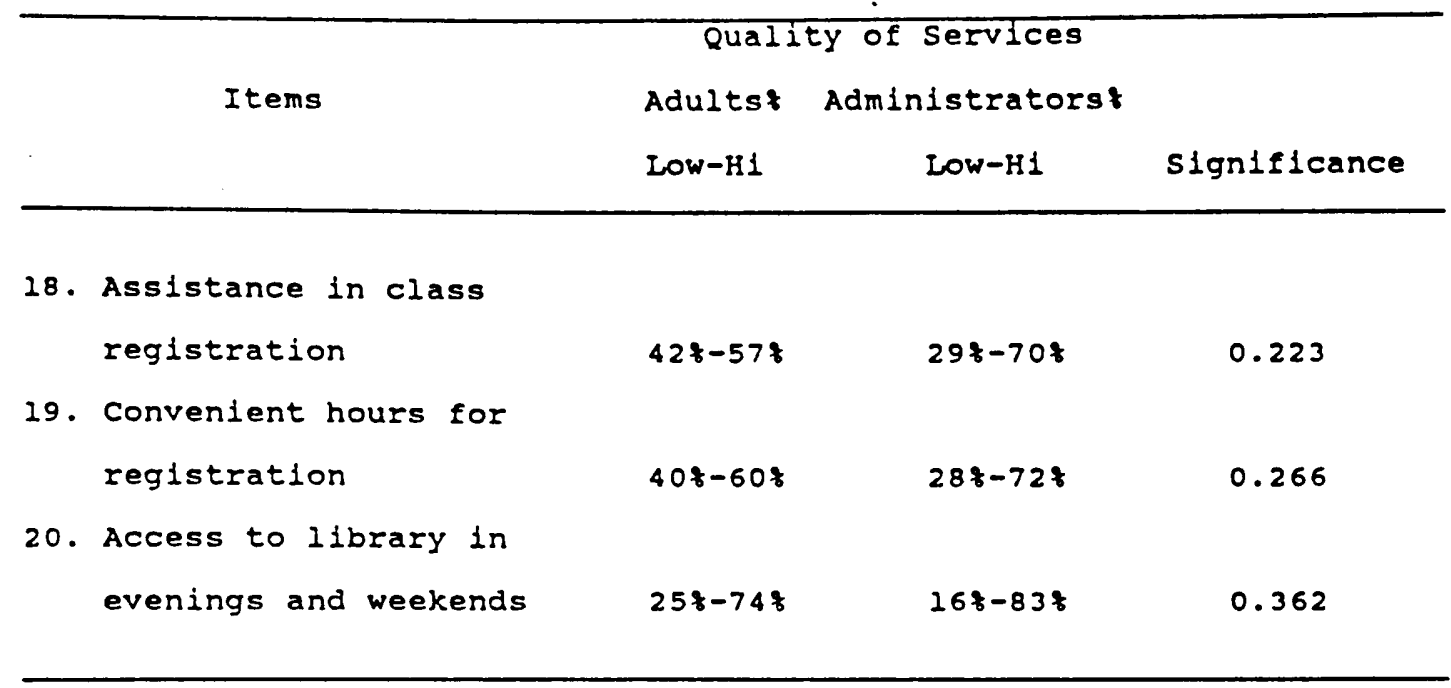

Note. Percents are based on those respondents answering 1-4 only. with low quality $=1$ and 2 , and high quality $=3$ and 4 .

student services, a five point scale was used in the CESSQ: N=non-existent, 1 =poor quality, 2 =moderate quality, $3=$ high quality and 4 =exceptional. These responses were then combined into two categories. For example, on item 1 , child care, $72 \%$ of the adult learners reported the service as low quality (1 or 2) while $27 \%$ reported the service as high quality (3 or 4 ). Conversely, $62 \%$ of administrators declared it as high quality $(2,3$ or 4$)$.

When comparing the responses by the adult learners, the five services having the lowest quality were: child care (72\%), food services (72\%), veterans 
affairs counseling ( $71 \%)$, orientation to campus life $(68 \%)$ and access to computers $(66 \%)$. In contrast, the administrators indicated these same services as follows: child care (62\%), food services (47\%), veterans affairs counseling (38\%), orientation to campus life (30\%) and access to computers (47\%); showing a distinct difference in the perception of administrators and adult learners toward food services, veteran affairs counseling and orientation to campus life.

Chi-square tests were used to test the difference between the adult learners and administrators' perception of the quality of services provided by the Institutions.

The biggest (chi-square) difference observed $(0.000)$ was for financial assistance, $56 \%$ of the adult learners rated it low while only $8 \%$ of the administrators did; followed by personal counseling $(0.001), 59 \%$ of adult learners rated it low while only $19 \%$ of administrators did so. others were orientation to campus life and veterans affairs counseling. Differences (chi-square) that were significant at the .05 level were: food services, vocational career counseling and admissions information. Therefore, the 
adult learners perceived the quality of services to be significantly lower than did the administrators in these seven areas.

This indicates a lack of awareness by the administration about some of the services provided to adult learners. No other significant differences in perception and quality were found between adult learners and administrators for the other 13 services.

The five services ranked by the adult learners as having the highest quality were: access to library in evenings and on weekends (74\%), convenient hours for registration (60\%), assistance in class schedule $(57 \%)$, academic counseling (56\%) and admissions information ( $54 \%$ ). Even for these five services, administrators recorded higher ratings than adult learners further illustrating that administrators rate the quality of those services higher than adult learners.

The five services having the lowest quality as perceived by the administrators were also low for the adult learners: child care $(62 \%$ for administrators and $72 \%$ for adult learners), assistance in planning a class schedule (52\% for both adult learners and administrators), medical or health care facility ( $52 \%$ 
for administrators and $65 \%$ for adult learners), food services ( $47 \%$ for administrators and $72 \%$ for adult learners and access to computers (47\% for administrators and $66 \%$ for adult learners).

The above mentioned data show that administrators tend to rate the quality of some key services higher than adult learners who use the services. This is a persistent issue with child care, medical or health care facilities, food services and access to computers.

The five services ranked by administrators and adult learners as having the highest quality were: access to library in evenings and weekends $(83 \%$ administrators and $74 \%$ adult learners), personal counseling ( $80 \%$ administrators and $40 \%$ adult learners), admissions information (76\% administrators, $54 \%$ adult learners), convenient hours for registration (72\% administrators and $60 \%$ adult learners) and suitable study areas (71\% for administrators and $51 \%$ adult learners).

The above data show a difference in the number of administrators and adult learners who assigned a high quality rank to the respective services. It is apparent that adult learners perceive they are not 
receiving the same level of services that administrators think they are providing. Administrators' Perception of Services Provided to Adult Learners versus Traditional students

The sixth question of this study asked: "Are there any differences in the services provided to adult learners versus traditional age students?" Table 8 presents the percentage of administrators indicating services provided to adult learners that are the same as those provided to traditional students. Services are ranked by the percentage of administrators who indicated a difference between the service provided to adult learners and traditional students; that is, the wider/smaller the difference, the higher/lower the ranking of one service.

Less than $50 \%$ of administrators reported that any of the 20 services were provided equally for adult learners and traditional students. The five services having the largest percentage of administrators stating they were not provided equally were: child care $(90 \%)$, study skills assistance (83\%), access to library in evenings and weekends (78\%), veterans affairs counseling ( $78 \%$ ) and food services ( $89 \%$ ). The five services where the larger percentage of 
Tabie 8

Percentrge of Administrators indicating similarlty of Gervices Provided

to Adult iearners and Traditional students

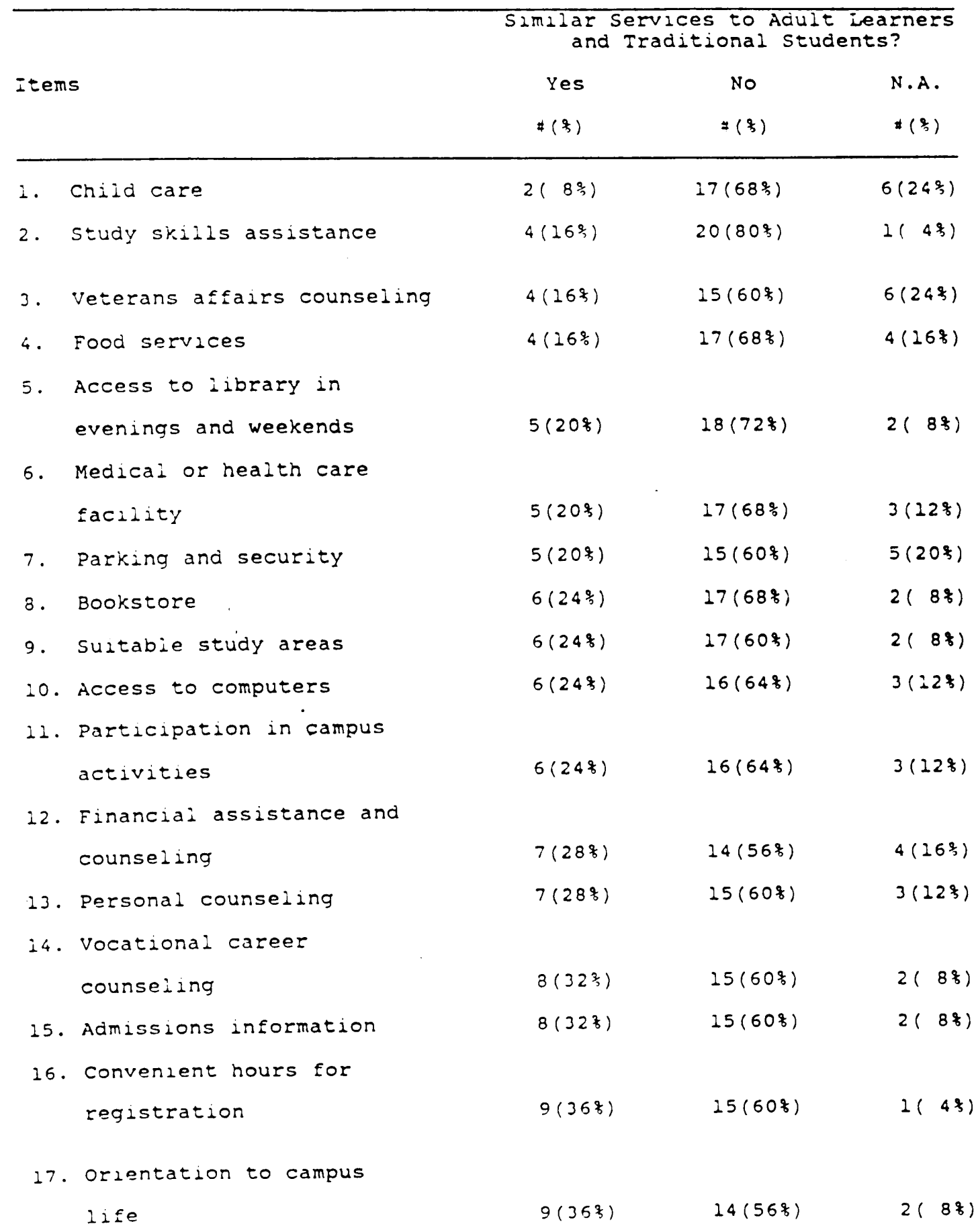


Table 8 (continued)

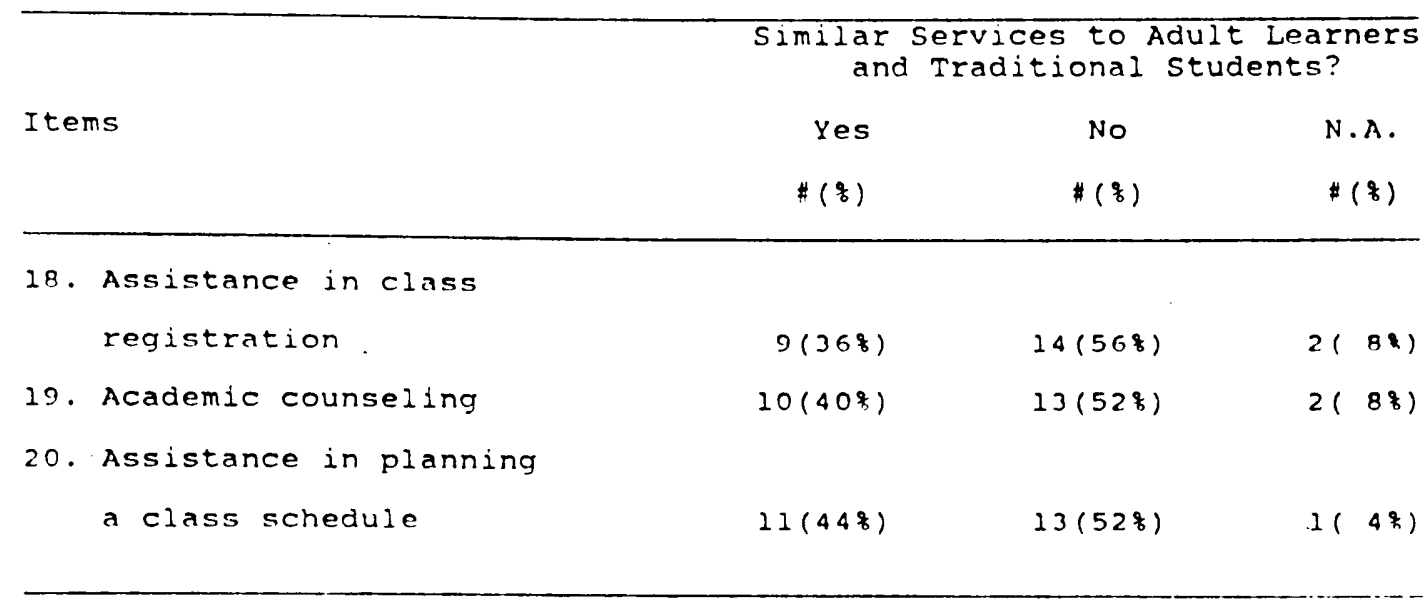

administrators indicated that the services provided to adult learners were the same as for traditional students were: assistance in planning a class schedule (44\%), academic counseling (40\%), assistance in class registration (36\%), orientation to campus life (368) and convenient hours for registration (368). The five services where the larger percentage of administrators indicated the services provided to adult learners were not the same as for traditional students were: study skills assistance $(80 \%)$, access to library in evening and weekends (72\%), child care (68\%), food services (68\%) and medical or health care facility (68\%). Comparison of Student Services Importance and Availability

Table 9 presents a comparison of the importance and availability of student services to adult learners and 
administrators, ranked by mean importance to adult learners.

A comparison of Table 8 and Table 9 shows that although the following five services were important to students, they were not made available equally for both traditional students and adult learners: access to computers, convenient hours for registration, parking and security, access to library in evenings and weekends and assistance in class schedule.

The five services ranked as most important to adult learners and their availability were: (figure in parenthesis is the average of adult learners responses in scale 1-4.) access to computers (3.55) $98 \%$, convenient hours for registration (3.49) 99\%, admissions information ( 3.42 ) $98 \%$, parking and security (3.34) $97 \%$ and assistance in class registration ( 3.30$) 99 \%$

These figures show that the most important services to adult learners are offered in all the institutions participating in the study, indicating their proximity and competition for the same adult learners.

The five services ranked as least important but available to adult learners were: veterans affairs 


\section{Learners and Administrators}

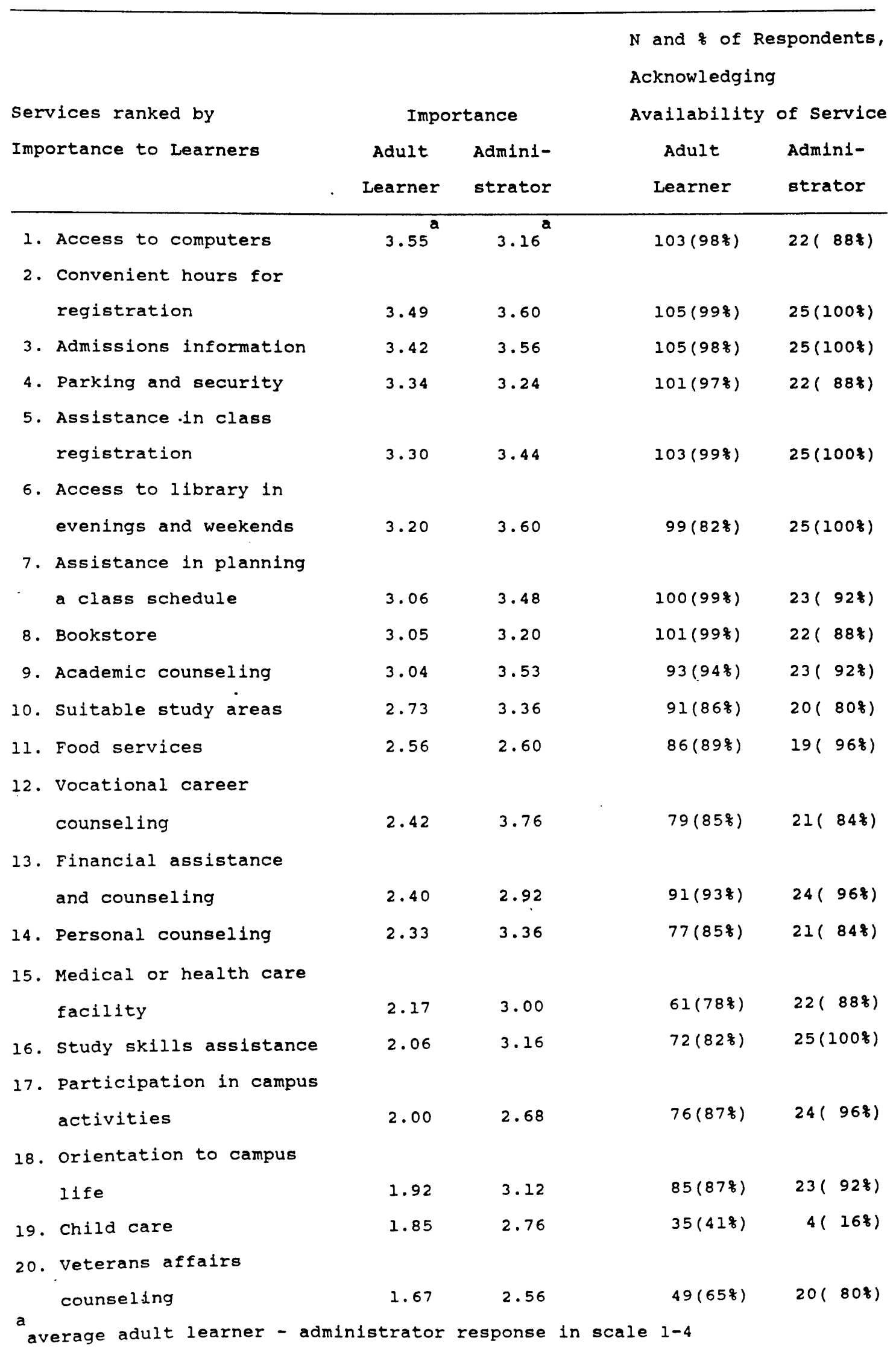


counseling (1.67) 65\%, child care (1.85) 41\%, orientation to campus life (1.92) 87\%, participation in campus activities $(2.0) 87 \%$ and study skills assistance $(2.06) 82 \%$.

The five services ranked as most important and available as perceived by administrators were: vocational career counseling (3.76) $84 \%$, suitable study areas (3.60) $80 \%$, convenient hours for registration ( 3.60$) 100 \%$, admissions information (3.56) $100 \%$ and assistance in planning a class schedule $(3.48) 92 \%$

The five services ranked the least important and available by administrators were: veterans affairs counseling (2.56) $80 \%$, participation in campus activities $(2.68) 96 \%$, child care (2.76) 16\%, financial assistance and counseling (2.92) 96\% and food services $(2.60) 96 \%$.

The data presented in Tables 2 through 9 indicate a substantial difference of perception toward some services among administrators and adult learners. Administrators participating in this study consistently evaluate the delivery of services higher than adult learners who are the recipients of such services. This emphasizes the importance of 
periodically assessing the students' perception of the services being provided to determine the level of satisfaction of all students receiving the services. This conclusion and others are discussed in the next chapter. 
V. SUMMARY, CONCLUSIONS AND RECOMMENDATIONS Summary

The purpose of this study was to examine the availability and quality of student services offered to adult learners in selected continuing higher education programs in Dade County, Florida. Factors contributing to the rise of adult students in five colleges and universities were investigated, and their impact on the student services offered. Some of the reasons for adult learners returning to school and the differences between traditional and non-traditional students were examined. Institutional, situational and dispositional barriers confronting adult students were explored.

The institutions in this study, five colleges and universities in Dade County, Florida were selected for the size of their adult enrollment, mission, design of their respective continuing education programs, and their location in a single urban county.

Data were collected from 107 students and 25 administrators using the continuing Education student Services Questionnaire (CESSQ). The instruments were administered by the researcher to one continuing education credit class and five administrators at each 
institution.

The study was designed to provide answers to six major questions:

1. What are the services being provided to adult learners by the five colleges and universities?

2. What is the quality of the services being provided as perceived by the administration?

3. What is the quality of the services being provided as perceived by the adult learners?

4. Are there any differences in the services being provided to adult learners by the five colleges and universities?

5. Are there any differences in the quality of the services as perceived by the administrators and adult learners?

6. Are there any differences between the services provided to adult learners and traditional college age students?

The data to answer these questions were collected through the continuing Education student Services Questionnaire (CESSQ). The questionnaire, one for administrators and one for adult learners, consisted of two parts. One part with eight demographic items and the second part with twenty items asking the 
availability and quality of 20 student services. Both contained the same twenty items showing the types of student services which should be offered. These twenty items were based on a study by silling (1984) concerning services provided to adult learners. Percentages for each item were calculated and analyzed. Two groups comprised the population for this study. One group were adult learners (undergraduate students, $N=107$ ) enrolled in credit courses offered by the continuing education unit of their institution.

Thirty-one percent ( $31 \%$ ) of the adult learner respondents were male, while $68 \%$ were female. The mean age for both was 28.87 years; $67 \%$ were between the ages of 18 and 30 while $28 \%$ were over 30 ; over half $(56 \%)$ were single, $32 \%$ were married and $11 \%$ divorced; nearly two-thirds (64\%) indicated English as their native language while $31 \%$ indicated Spanish; $40 \%$ had some type of graduate experience, $39 \%$ indicated having a bachelor's degree and $49 \%$ reported as having completed two years of college. The average or. typical adult learner surveyed in this study was a female, 28 years old, single, of English speaking background having completed two years of college, and 
with an income between $\$ 15,000$ and $\$ 21,000$ per year. This profile is supported by Apps (1981).

The second group were administrators in the areas of Admissions, Financial Aid, Registration, student Services and Continuing Education from the five colleges and universities in Dade County, Florida $(\mathrm{N}=25)$. $92 \%$ were female, while eight percent were male; the mean age for both genders was 41.7 years; $64 \%$ were between the ages of 36 and 60 , while $28 \%$ were between the ages of 25 and $35 ; 28 \%$ were single, $50 \%$ married and $12 \%$ divorced; $72 \%$ reported English as their native language while $20 \%$ indicated Spanish; $68 \%$ had some graduate experience, and $32 \%$ were college graduates. The average administrator surveyed was a female, 41 years old, married, of English speaking background, having completed a graduate degree and with an annual income between $\$ 25,000$ and $\$ 30,000$. Following are the results for each of the questions addressed in this study.

Question one. What are the services being provided to adult learners by the five colleges and universities? The data finds the services indicated by the adult learners as most available were: convenient hours for registration, assistance in class 
registration, assistance in planning a class schedule, bookstore, access to computers, admissions information and parking and security. The least available services as indicated by adult learners were: child care, veterans affairs counseling, medical or health care facilities, study skills assistance and access to library in evenings and weekends.

An overview of responses by institutions shows that only the following nine out of 20 services received a $100 \%$ response as available at one or more institutions: admissions information ( 3 institutions), convenient hours for registration ( 3 institutions), assistance in class registration ( 3 institutions), assistance in planning a schedule ( 1 institution), access to library in evening and weekends ( 3 institutions), parking and security ( 1 institution), food services ( 1 institution), bookstore ( 2 institutions) and access to computers ( 3 institutions). The responses also show that there is not a major difference in the services being provided to adult learners by the five colleges and universities.

The seven most available services indicated by the administrator respondents were: admission 
information, convenient hours for registration, assistance in class registration, study skills assistance, access to library in evenings and weekends, financial aid assistance and counseling and participation in campus activities. Conversely, the least available services according to the administrators were: child care, suitable study areas, personal counseling, vocational career counseling, medical or health care facilities and parking and security. Both adult learners and administrators agree on the poor availability of child care.

The data further show that a high percentage of administrators and students agreed on the availability of the following services: admissions information, convenient hours for registration, assistance in class registration, assistance in planning a class schedule, orientation to campus life, academic counseling and financial aid assistance and counseling.

A higher percentage of administrators than adult learners indicated the following services were provided: study skills assistance, access to library in evenings and weekends, medical or health care facility and veterans affairs counseling. A lower 
percentage of administrators than adult learners indicated the following services were provided: bookstore, access to computers, parking and security and food services.

Questions Two, Three and Five. What is the quality of the services provided as perceived by adult learners (question three) and administrators (question two); and are there any differences in the quality of those services as perceived by adult learners and administrators (question five)? Data to answer these questions were provided through the CESSQ. For the purpose of this study a three (high quality) or four (exceptional quality) on a four point scale was considered a measure of quality. Percentages of administrators who answered three or four were compared to those who answered one (poor quality) or two (moderate quality).

Chi-square tests were used to test for differences between adult learners and administrators' perception of the quality of services provided by the institutions. The biggest difference observed $(0.000)$ was for financial assistance. Statistical differences significant at the .01 level were: Financial assistance and counseling, personal counseling, 
orientation to campus life and veterans affairs. Differences significant at the .05 level were: food services, vocational career counseling and admissions information.

In all the above services, a significant percentage of adult learners rated the quality of the services lower than the administrators, showing a lack of awareness in part of the administration about the impact those services are having on their adult learners.

The services of the lowest quality as perceived by adult learners were: child care, food services, veterans affairs counseling, orientation to campus life and access to computers. The services ranked by the adult learners to be of the highest quality were: access to library in evenings and weekends, convenient hours for registration, assistance in class schedule, academic counseling and admissions information.

The services with the lowest quality as perceived by administrators were: child care, assistance in planning a class schedule, medical or health care facility, food services and access to computers. A larger percentage of adult learners indicated low quality for the same services, showing a greater 
dissatisfaction by adult learners than by administrators with these services.

The highest quality services ranked by the administrators were: access to library in evenings and weekends, personal counseling, admissions information, convenient hours for registrations and suitable study areas. A lower percentage of adult learners indicated high quality for the same services. showing once again a difference in the perception of the quality of services between administrators and adult learners.

A comparison of the importance of student services and their availability as indicated by adult learners and administrators showed the services ranked as most important to adult learners were: access to computers, convenient hours for registration, admission information, parking and security and assistance in class registration. Conversely, a high percentage of adult learners indicated availability of those services at their institutions, thus, the most important services to adult learners are offered in all institutions participating in the study.

The services ranked least important to adult learners were: veterans affairs counseling, child 
care, orientation to campus life, participation in campus activities and study skills assistance. only orientation to campus life, participation in campus activities and study skills assistance were available in all participating institutions. This data shows that child care is rarely offered by the participating institutions due to the low interest indicated by adult learners.

The services ranked as most important to administrators were: vocational career counseling, suitable study areas, convenient hours for registration, admissions information and assistance in planning a class schedule. A high percentage of administrators indicated availability of those services at their institutions.

The services ranked as least important by administrators were: veteran affairs counseling, -participation in campus activities, child care, financial assistance and counseling and food services. With the exception of child care, a large number of administrators indicated availability of those services at their institutions. The data on this section showed that the services ranked as most important to adult learners and administrators were 
offered in all institutions participating in this study. Of the services ranked as least important to adult learners and administrators, only child care was not available in most institutions.

Question Four. Are there any differences in the services being provided to adult learners by the five colleges and universities? Data to answer this question were provided through the CESSQ. The percentages for each item of the five categories (nonexistent, poor quality, moderate quality, high quality and exceptional quality) were calculated and compared among the five institutions.

The data did not show a major difference in the services provided to adult learners by the five colleges and universities. All twenty services studied were provided by the five institutions with child care being categorized as the least offered (only $41 \%$ adult learners indicated its existence); and convenient hours for registration, assistance in class registration, assistance in planning a class schedule, book store and admission information as most offered. This is perhaps attributable to their proximity and the similarity of their student body. It also denotes the keen competition existing among the five 
institutions for the recruitment and retention of adult learners from the same area.

Question Six. Are there any differences in the services provided to adult learners versus traditional college age students? Data to answer this question also came from the CESSQ. Yes or no answers given by administrator respondents determined whether the delivery of the service was any different for adults than for traditional students. Less than $50 \%$ of administrators reported that the 20 services were provided equally for adult learners and traditional students.

The services that the greatest percentage of administrators said were not provided equally were: child care, study skills assistance, access to library in evening and weekends, veterans affairs counseling and food services.

The services equally provided to adult learners and traditional students were: assistance in planning a class schedule, academic counseling, assistance in class schedule, orientation to campus life and convenient hours for registration.

A comparison of the data further shows that although the following services were important to 
adult learners, they were not provided equally for traditional students and adult learners: access to computers, convenient hours for registrations, parking and security, access to library in evening and weekends, and assistance in class schedule. This shows the obvious accessibility that traditional students have to services during the day, but are not available to adult learners in the evening. Conclusions

A review of the data indicate the following: An overview of responses by administrators showed that only the following services were $100 \%$ available at one or more institutions: admissions information, convenient hours for registration, assistance in class registration, assistance in planning a class schedule, access to the library in evenings and weekends, parking and security, food service, bookstore and access to computers.

The data also show that administrators and students agree on the availability of assistance in class registration and admission information but disagree on study skills assistance (100\% administrators and $82 \%$ adult learners). of the 20 services studied, the services most 
important to adult learners at all five institutions are: access to computers, convenient hours for registration, admissions information, parking and security, assistance in class registration, access to library in evenings and weekends, assistance in planning a class schedule, bookstore, academic counseling and suitable study areas.

The services least important to adult learners are: veterans affairs counseling, child care, orientation to campus life, participation in campus activities, study skills assistance, medical or health care facilities, personal counseling, financial assistance and counsel, vocational career counseling and food services. Adult learners do not express need for orientation to campus life on their campuses. Their primary involvement on campus is class attendance.

The services most available at institutions, according to adult learners were: convenient hours for registration, assistance in class registration, assistance in planning a class schedule, bookstore, access to computers, admissions information, parking and security, academic counseling, financial assistance and counseling and food services. There is 
a wide discrepancy between the provision of financial aid for adult learners and the perceived need for it. The least available services according to adult learners are: child care, veterans affairs counseling, medical or health care facility, study skills assistance, access to library in evenings and weekends, personal counseling, vocational career counseling, suitable study areas, participation in campus activities and orientation to campus life. The data also show that a high percentage of administrators and students agree the following services are provided. Admissions information, convenient hours for registration, assistance in class registration, assistance in planning a class schedule, orientation to campus life, academic counseling and financial aid.

Areas where a high percentage of administrators indicate the service is provided, but a lower percentage of adult learners agree were: study skills, access to library in evenings and weekends, medical and health care facilities, and veterans affairs counseling.

Although the following services were important to adult learners, they were not provided equally for 
traditional students and adult learners: access to computers, convenient hours for registration, parking and security, access to library in evenings and weekends and assistance in class schedule.

The following conclusions are derived from the analysis of the data obtained in this study.

1. There is a difference in perception between adult learners and administrators about the quality of student services provided by the five colleges and universities. A greater percentage of adult learners rated the quality of most services lower than administrators.

2. There is not any major difference in the services provided to adult learners by the five colleges and universities although there is a difference in the services provided to adult learners and traditional age students (full time, under 25) in the five colleges and universities.

3. The most important services to adult learners are offered in all five colleges and universities, indicating a similarity of services among institutions.

4. Institutional barriers are prevalent to adult learners, but are not seen as prevalent to 
administrators and although situational barriers are prevalent, they are not seen as a problem to adult learners.

5. Services available to overcome dispositional barriers are not seen as important to adult learners surveyed, although services important to adult learners were not offered equitable for traditional students and adult learners.

Recommendations

The data examined in this study have shown the availability and quality of student services offered to adult learners in selected continuing education programs in Dade County, Florida. The following recommendations are made as the result of examining the data on services and the environmental conditions which each institution must create in order to attract and retain adult learners:

1. When a college or university wants to develop a substantial adult constituency, it should modify its mission statement to clearly express a commitment to adults, and should have this change fully understood and endorsed by the governing board of the institutions.

2. The institution's long-range planning must 
consistently address the needs of adults as a major constituency of the university.

3. The institution will need to develop policies regarding scheduling of classes and teaching methods to accommodate adult students.

4. The institution should place significant emphasis on adult student needs and interests as well as on faculty preferences and administrative conveniences.

5. The academic rules and regulations must be made more responsive to adult students' needs for streamlined bureaucratic procedure, and, more importantly, they must actively attempt to seek equity in the application of rules and providing services to students of varying ages and circumstances.

6. The institution must recognize that adult students operate in different time frames from traditional students and, thus, require longer, operating hours for many university functions.

7. As part of its overall managerial practice, the institution needs to develop evaluation and objective-setting processes which speak specifically and uniformly to identifying and meeting the needs of aduIt students. 
8. Student services, from the highest to the lowest levels, must develop processes and positions having specific responsibility and authority for identifying and meeting the service needs of adults.

9. In each area of student services the needs of adult students must be addressed consistently and equitably with the needs of younger students.

10. Adults bring a great deal of life experiences into the educational setting. An invaluable asset to be acknowledged, tapped and used in the delivery of student services.

In closing, perhaps the easiest way to summarize these recommendations is to lift some words from the final report of the Carnegie Commission on Nontraditional study (1976) regarding how a studentcentered institution should view itself:

"The institution puts the students first and the institution second, concentrates more on the former's need than the latter's convenience, encourages diversity of individual opportunity rather than uniform prescription, and de-emphasizes time, space, and even course requirements in favor of competence, and where applicable, performance. 
It has concern for the learners of any age and circumstance, for the degree aspirant as well as the person who finds sufficient reward in enriching life through constant, periodic or occasional study." (Gold, 1973 p.15) as cited by Carnegie Commission on Non-traditional study. Recommendations for further research.

The researcher recognizes the need for further research in the area of student services.

1. This study should be replicated in other areas of the country in order to match adult learners' needs, with geographical location to ascertain if the current and future student services needs found in this study are consistent.

2. The present study did not include community colleges. Further studies should include community colleges in order to validate the student services needs of adult learners in community college settings. 3. The researcher attempted to include historically black colleges. Due to lack of funds and time constrain, it was decided not to include them in this study. It is strongly recommended that further research be done in the area of student services provided to adult learners in continuing education 
programs sponsored by historically black colleges and universities.

4. Further research should be done in the area of administrators vs adult students perception of student services offered at institutions of higher learning.

5. Finally, further study should be done about the relationship between student services and retention of adult students at continuing Education Programs. 
A P P E N D I C E S

APPENDIX A

APPENDIX B

APPENDIX C

APPENDIX D

APPENDIX E

APPENDIX F

APPENDIX G

APPENDIX H
Continuing Education student Services Questionnaire (Administrators)

Continuing Education student services Questionnaire (Adult Learners)

Continuing Education Students student Services Survey used in the Pilot study

Dean of Continuing Education Questionnaire used in Pilot study

Summary of Pilot study Responses

Letter to Dean of Continuing Education Programs

Letter from Dr. Smith to Deans of Continuing Education Programs

List of individuals to receive letters requesting permission to administer questionnaires 


\section{(APPENDIX A) \\ CONTINUING EDUCATION \\ STUDENT SERVICES QUESTIONNAIRE}

(ADMINISTRATORS)

Thank you for agreelng to complete this questionnalre on services offered to adult learners enrolled in the continuing Education Program at your institution.

This is a research study to examine the needs of adult learners and how those needs are belng met at your institution. Your help in making this study as successful as posslble is greatly appreclated. Please be assured that no names w1ll be used in the recording and reporting of the data recelved.

\section{BIOGRAPHICAL DATA}

1. SEX: Male

2. AGE :

3. MARITAL STATUS:

4. Native LANGUAGE:

5. EDUCATIONAL LEVEL:
Female

single

Married

Divorced

Wlowed

English

span1sh

French

other

Less than High school

HIgh School Graduate

Two years or less of College

College Graduate

Graduate school

6. PURPOSE OF TAKING THIS COURSE: 
7. MY PRESENT POSITION IS BEST DESCRIBED AS:

Administrator of cont. Ed.

Administrator not in Cont. Ed.

Faculty member of cont. Ed.

Faculty member not in cont. Ed.

student

8. INCOME LEVEL:

Under 10,000

10,000 to 20,000

20,000 to 35,000

35,000 to 50,000

over 50,000 
Following is a list of services provided by institutions of higher education to their students. Please indicate your answer by circling the most appropriate number.

\begin{tabular}{|c|c|c|c|c|c|c|c|c|c|c|c|}
\hline \multirow[b]{2}{*}{ ervices } & \multicolumn{4}{|c|}{$\begin{array}{l}\text { The quality of this } \\
\text { service at this } \\
\text { institution is: }\end{array}$} & \multicolumn{7}{|c|}{$\begin{array}{l}\text { How important is it } \\
\text { to you that this service } \\
\text { be provided? }\end{array}$} \\
\hline & \multicolumn{4}{|c|}{$\begin{aligned} N= & \text { Nonexistent } \\
1= & \text { Poor quality } \\
2= & \text { Moderate } \\
& \text { quality } \\
3= & \text { High quality } \\
4= & \text { Exceptional }\end{aligned}$} & \multicolumn{4}{|c|}{$\begin{aligned} 1= & \text { Non important } \\
2= & \text { Fairly important } \\
3= & \text { Very important } \\
4= & \text { Extremely } \\
& \text { important }\end{aligned}$} & \multicolumn{3}{|c|}{$\begin{array}{l}\text { Is the delivery of this } \\
\text { service any different for } \\
\text { adults that for traditional } \\
\text { students? }\end{array}$} \\
\hline Admission Information & N 1 & 2 & 3 & 4 & 1 & 2 & 3 & 4 & Yes & No & \\
\hline Convenient hours for registration & N 1 & 2 & 3 & 4 & 1 & 2 & 3 & 4 & Yes & No & \\
\hline Assistance in class registration & N 1 & 2 & 3 & 4 & 1 & 2 & 3 & 4 & Yes & No & \\
\hline Assistance in planning a class schedule & $N+1$ & 2 & 3 & 4 & 1 & 2 & 3 & 4 & Yes & No & \\
\hline Orientation to campus life & $N$ & 2 & 3 & 4 & 1 & 2 & 3 & 4 & Yes & No & \\
\hline Academic Counseling & $N$ & 2 & 3 & 4 & 1 & 2 & 3 & 4 & Yes & No & \\
\hline Vocational Career Counseling & $N$ & 2 & 3 & 4 & 1 & 2 & 3 & 4 & Yes & No & \\
\hline Personal Counseling & $\mathrm{N}$ & 2 & 3 & 4 & 1 & 2 & 3 & 4 & Yes & No & \\
\hline Financial Assistance and counseling & $N$ & 2 & 3 & 4 & 1 & 2 & 3 & 4 & Yes & No & \\
\hline Veterans Affairs Counseling & $N$ & 2 & 3 & 4 & 1 & 2 & 3 & 4 & Yes & No & \\
\hline Study skills assistance & $N$ & 2 & 3 & 4 & 1 & 2 & 3 & 4 & Yes & No & \\
\hline Suitable study areas & N & 2 & 3 & 4 & 1 & 2 & 3 & 4 & Yes & No & \\
\hline $\begin{array}{l}\text { Access to library in evening and } \\
\text { weekends }\end{array}$ & N & 2 & 3 & 4 & 1 & 2 & 3 & 4 & Yes & No & 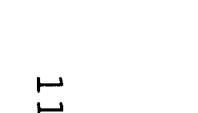 \\
\hline Medical or health care facility & $N$ & 2 & 3 & 4 & 1 & 2 & 3 & 4 & Yes & No & $N$ \\
\hline Participation in campus activities & $N$ & 2 & 3 & 4 & 1 & 2 & 3 & 4 & Yes & No & \\
\hline Parking and security & N 1 & 2 & 3 & 4 & 1 & 2 & 3 & 4 & Yes & No & \\
\hline
\end{tabular}




\begin{tabular}{|c|c|c|c|c|c|c|c|c|c|c|c|}
\hline Food Services & $\mathrm{N}$ & 1 & 2 & 3 & 4 & 1 & 2 & 3 & 4 & Yes & No \\
\hline Bookstore & N & 1 & 2 & 3 & 4 & 1 & 2 & 3 & 4 & Yes & No \\
\hline Child care & $\mathrm{N}$ & 1 & 2 & 3 & 4 & 1 & 2 & 3 & 4 & Yes & No \\
\hline Access to computers & $\mathrm{N}$ & 1 & 2 & 3 & 4 & 1 & 2 & 3 & 4 & Yes & No \\
\hline
\end{tabular}

Thank you once aga in for your participation 


\section{( APPENDIX B ) \\ CONTINUING EDUCATION \\ STUDENT SERVICE QUESTIONNAIRE}

\section{( ADULT LEARNERS)}

Thank you for agreelng to complete this questionnalre on services offered to adult learners enrolied in the continulng Education Program at your institution.

This is a research study to examine the needs of adult learners and how those needs are belng met at your institution. Your help in making this study as successful as possible is greatly appreclated. Please be assured that no names will be used in the recording and reporting of the data recelved. BIOGRAPHICAL DATA

1. SEX: Male

Female

2. AGE :

3. MARITAL STATUS:

single Married DIvorced Wldowed

4. NATIVE LANGUAGE: English_ spanish French other

5. EDUCATIONAL LEVEL: Less than High School

High School Graduate

Two years or less of college College Graduate

Graduate school

6. PURPOSE FOR TAKING THIS COURSE:

(adult learners only) 
115

7. MY PRESENT POSITION IS BEST DESCRIBED AS:

Administrator of Cont. Ed.

Administrator not in Cont. Ed.

Faculty member of Cont. Ed.

Faculty member not in cont. Ed.

student

8. INCOME LEVEL:

Under 10,000

10,000 to 20,000

20,000 to 35,000

35,000 to 50,000

Over 50,000 
Following is a list of services provided by institutions of higher education to their students. Please indicate your answer by circling the most appropriate number.

The quality of this service at this institution is: How important is it to you that this service be provided?

$$
\begin{array}{ll}
N=\text { Non-existent } & 1=\text { Not important } \\
1=\text { Poor Quality } & 2=\text { Fairly important } \\
2=\text { Moderate quality } & 3=\text { Very important } \\
3=\text { High quality } & 4=\text { Extremely important } \\
4=\text { Exceptional } &
\end{array}
$$

Admissions Information

Convenient hours for registration

3 Assistance in class registration

4 Assistance in planning a class schedule

5 Orientation to campus life

6 Academic Counseling

7 Vocational Career Counseling

8 Personal Counseling

9 Financial Assistance and counseling

10 Veterans Affairs counseling

11 Study skills assistance

12 Suitable study areas

13 Access to library in evening and weekends

14 Medical or health care

\begin{tabular}{|c|c|c|c|c|c|c|c|}
\hline$N$ & 1 & 2 & 3 & 4 & 1 & 2 & 3 \\
\hline$N$ & 1 & 2 & 3 & 4 & 1 & 2 & 3 \\
\hline$N$ & 1 & 2 & 3 & 4 & 1 & 2 & 3 \\
\hline & 1 & 2 & 3 & 4 & 1 & 2 & 3 \\
\hline
\end{tabular}
facility

15 Participation in campus activities

16 Parking and security

17 Food Services

18 Bookstore

19 Child Care

20 Access to Computers
$\begin{array}{lllll}N & 1 & 2 & 3 & 4\end{array}$

$\begin{array}{lllll}N & 1 & 2 & 3 & 4\end{array}$

$N 1234$

$\begin{array}{lllll}N & 1 & 2 & 3 & 4\end{array}$

$\begin{array}{lllll}N & 1 & 2 & 3 & 4\end{array}$

$\begin{array}{lllll}N & 1 & 2 & 3 & 4\end{array}$

1234

$\begin{array}{llll}1 & 2 & 3 & 4\end{array}$

1234

$\begin{array}{llll}1 & 2 & 3 & 4\end{array}$

$\begin{array}{llll}1 & 2 & 3 & 4\end{array}$

$\begin{array}{llll}1 & 2 & 3 & 4\end{array}$

$\begin{array}{lllllllll}N & 1 & 2 & 3 & 4 & 1 & 2 & 3 & 4\end{array}$

$\begin{array}{lllll}N & 1 & 2 & 3 & 4\end{array}$

$123 \quad 3 \quad 4$

N. 121230

1234

$\begin{array}{lllllllll}N & 1 & 2 & 3 & 4 & 1 & 2 & 3 & 4\end{array}$

$\begin{array}{lllllllll}N & 1 & 2 & 3 & 4 & 1 & 2 & 3 & 4\end{array}$

$\begin{array}{lllllllll}N & 1 & 2 & 3 & 4 & 1 & 2 & 3 & 4\end{array}$

$\begin{array}{lllllllll}N & 1 & 2 & 3 & 4 & 1 & 2 & 3 & 4\end{array}$

$\begin{array}{lllllllll}N & 1 & 2 & 3 & 4 & 1 & 2 & 3 & 4\end{array}$

$\begin{array}{lllllllll}N & 1 & 2 & 3 & 4 & 1 & 2 & 3 & 4\end{array}$

$\begin{array}{lllllllll}N & 1 & 2 & 3 & 4 & 1 & 2 & 3 & 4\end{array}$ 
(APPENDIX C)

CONTINUING EDUCATION STUDENTS

STUDENT SERVICES SURVEY USED

IN THE PILOT STUDY

Thank you for agreelng to complete this survey on services offered to adult learners in the continuing Education Program at Florida International University.

This is a pllot study of a larger study to be conducted later this year. Your help in making this study as effective as possible is greatly appreclated.

your name is not necessary, and please be assured that all information will be kept confldentlal.

\section{DATA FORM}

1. SEX:

Male

Under 35

2. AGE:

3. Marital status:

single,

Divorced

4. Native language:

English

spanish
Female

Over 35 
7. INCOME LEVEL: Under 10,000

$$
\begin{aligned}
& 10,000 \text { To } 20,000 \\
& 20,000 \text { To } 35,000 \\
& \text { over } 35,000
\end{aligned}
$$

8. Does your occupation require upgrading or mastery of new skilis on a regular or perlodlc basic?

Yes

No

9. Are these activities mandatory?

Yes

No

10. Do you voluntarily participate in Adult Education activities for professlonal development?

Yes

No

If yes, what type, where, frequency?

11. Do you voluntarily particlpate in Adult Education activities for personal interest?

Yes

No

If yes, what type, where, frequency?

12. What type of student services are avallable to you?

13. What type of student services do you use most frequent?

14. How adequate are those services? 
119

15. What type of student services do you feel should be offered that are not presently available? Why?

16. What is your perception of the continuing Education staff?

17. What are your feelings towards your educational program?

18. Are there any additional remarks you would like to make regarding your educational experience at F.I.U. Continuing Education Program?

THANK YOU FOR YOUR TIME AND EFFORT IN COMPLETING THIS QUESTIONNAIRE. 


\author{
(APPENDIX D) \\ DEAN OF CONTINUING EDUCATION \\ QUESTIONNAIRE USED IN PILOT STUDY
}

1. How is Continuing Education deflned at this Unlversity?

2. Please give a general description of Continuing Education at this university. In other words, Continuing Education at F.I.U. 1s:

3. What is the organizational placement of the program? Give either a description or an organizational chart.

4. What is the slze of your staff? Please describe functions.

5. What type of students do you serve? Please, give a brief proflie.

6. What is your definition of student services?

7. What student services do you offer? 
8. What student services would you like to offer, but are not avallable at this time?

9. What is the average faculty-student ratio? what is the minlmu, maximum?

10. Who is your staff is primarily responsible for providing student services? 
(APPENDIX E)

SUMMARY OF PILOT STUDY RESPONSES

8 Male 8 Female All under $25 \quad \mathrm{~N}=16$

Question

Response

\begin{tabular}{l|l} 
Voluntary Participation in & 1 \\
\hline Types of Services avaliable & $\begin{array}{l}\text { Reglstration by phone } \\
\text { Computer Lab }\end{array}$ \\
Health Services \\
Career development \\
Job placement
\end{tabular}

Most frequently used services

Library

Registration by phone

Computer Lab

Adequacy of Services

L1brary - Very Good

Computer Lab - Not enough terminals

Crowded

Not enough time

No place to study in Library

Recommended Services

Better computer labs

Tutoring 6

Better registration procedures

I. Chlld Care

1 Additional study Area

Continuing Education staff

Perception

Good, Adequate, Helpful

Attitude toward continuing

Education Program

Good,

\section{Impress Ive}

Tendency towards eliminating students

helping them 
(APPENDIX F)

Letter to Dean of Cont. Ed. Programs

Florida International University

The State l'minersily. of Florida at Niami

Auqust 30,1988

Dr. Nennis Tarr

Dean, Cont inuing Education

School of Continuing Studies

University of $\mathrm{Miami}$

P.ก. Box 248005

Coral rables, F1. 33124

Dear $\mathrm{nr}$. Tarr:

This is a follow up to our conversation concernina the administration of a questionnaire to selected administrators and students at your institution. This study will examine the needs of adult learners enrolled at vour institution.

As we discussed, this is oart of a dissertation research study for a doctorate (Fd.D.) in Adult Education and Human Resource nevelopment.

Enclosed is a letter fram my major professor, Dr. Nouglas H. Smith indicating his approval of my topic and research methodoloqy. In the near future, I will he contacting your office in order to set up a time and place to administer the questionnaire.

Thank vou in advance for your willinnness to participate in this studv, which I will be happy to share with you once it is completed.

Sincerely,

Roberto Barranan, Ir.

Colleqe of Erfucation

Universily Park. Miami. Florida 33199

(305) 5542724

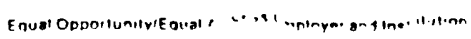


(APPENDIX G)

Letter from Dr. Smith to Deans of Cont. Ed. Programs

\section{Florida International University}

The State limemstly of Florida al Mham

Division of Educational Policy and Human Resource Development

Auqust 30,1989

Dr. Dennis Tarr

Dean, Cont inuina Education

School of Continuing Studies

Universitv of Miami

P. . Rox 249025

Coral Gables, Fl. 33124

near Mr. Tarr:

This letter is intended to support the research study hy Roberto Barraaan, a doctoral candidate under my supervision, for an Ed.n. in Adult Education and Human Resource Develooment.

As exnlained by Mr. Barraqan, he is conductino a dissertation study examining the needs of adult learners and how those needs are being met at $f$ ive colleaes and universities in Dade County.

His intention is to interview and administer a auestionnaire to selected administrators and adult learners to examine the student services beina provided for adult learners. You will be fully informed of the administrators to be interviewert. You will also be asked to helo select the adult learners who will complete the questionnaire.

I will anpreciate any assistance you provide $\mathrm{Mr}$. Barragan towards the comoletion of this important research study.

If vou have any questions, or need further information, do not hesitate to contact me at 554-3205.

Sincerely,

nounlas H. Smith, Ph.n.

Associate Professor

Adult Fducation and Human

Resource Develonment

College ol Education

Universily Park. Miami. Florida 33199

(305) 554.2724

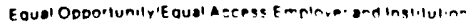


(AFFEHDIX H)

\author{
List of Individuals to Peceive Iettors \\ Roquesting Fermission to Administer ouestionmaires
}

Dr. Carol Ann Baldyga

Dean, Continuing Education

Florida International university

(llorth Campus)

II.E. 151 st. and Biscayne Blvd

llorth lliami, Florida 33181

Dr. Donnis Tarr

Dean, Continuing Education

school of continuing studies

University of Miami

E. O. BOX > 4anO5

Coral Gablos, Florida 33124

Dr. Faul wiosor

ncademic Dean

st. Thomas University

$16.400 \mathrm{lW} 32 \mathrm{nd}$ Avenue

lliami, Florida 33054

Ms. Angola Fontain

st. Thomas University

continuing Education

Falm Springs Mall

556 is 49 th street

Hialoah, Fiorida 33112
Dr. Willie C. Robinson

Fresident

Florida Hemorial College

15800 N.W. 42 nd Avenue

lliami, Florida 33054

Dr. C.T. Wright

Vice Fresident Academic Affairs

Florida Memorial College

15800 N.W. 42 nd Avenue

Miami, Florida 33054

Ms. Erma Williams

Admissions office

Florida Memorial College

15800 N.W. 42 nd Avenue.

Miami, Florida 33054

sister Marilyn Morman

Dean, Continuing Education

Barry University

11300 N.E. 2 nd Avenue

Mlami, Florida 33161 
B I B I I O G R A P H Y 
Abraham, W. , Poppen, P. \& Ricks, D. (Eds.) (1976). Humanism and Behaviorism: Dialogue and Growth. New York: Pergamon Press.

Alford, J. L. An Assessment of the student support Services Needs of Selected Adult College Students. (Doctoral Dissertation, The University of Cincinnati, 1980). Dissertation abstracts international, (8029710).

Anderson, R. C. \& Ausubel, D. P. (Eds.) (1965). Readings in the Psychology of Cognition. New York: Holt, Rinehart and Winston.

Apps, J. W. (1980). Six influences on adult education in the 1980's. Iifelong Learning: The Adult Years, $3,4-7$

Arenberg, D. I. \& Robertson, Elizabeth A. (1975). The Older Individual as a Learner. Learning for Aging. Washington, D. C.: Adult Education Association of the U.S.A.

Babcock, R. J. (1982). How to succeed in College: A guide to the nontraditional student. New York: Association of American Publishers.

Baltes, P. B. \& Warker, Shaie K. (1973). Iife-span Developmental Psychology. New York: Academic Press.

Bengtson, V. I. (1973). The Social Psychology of Aging. Indianapolis: The Bobs-Merrill Company, Inc.

Bergevin, P. (1967). A Philosophy for Adult Education New York: The seabury Press.

Bettandorf, R. S. (1980). Adult Student Support Services: Administrative Perceptions on Adequacy and Importance. (Doctoral dissertation, The University of Mississippi. (1980). Dissertation abstracts international. $(8108751)$.

Boyd, H. B. (1929). Conflicting Psychologies of Learning. New York: Heath Publishing Company. 
Boyer, C. H. (1979). Philosophical Perspectives for Education. Chicago: Scott, Foresman and Co.

Brandenberg, J. B. (1974). The needs of women returning to school. Personnel and Guidance Journal, 53, 11-18.

Brookfield, S. K. \& Milton (1983). Adult Learners, Adult Education and the Community. London: open University Press.

Bruner, J. (Ed.) The act of discovery. Readings in The Pychology of Cognition. Anderson and Ausubel Publishers.

Buhler, C. (1961). Meaningful Living in Mature Years. New York: oxford University Press.

Burton, C. C. (1958). Adult Education in Transition. University of Southern California Press. p. 61.

Center for Research and Development in Higher Education (1979). An Evaluation Look at Nontraditional Postsecondary Education. Washington, D. C.: U.S. Government Printing office.

Christensen, F. (1980). Equipping faculty to serve lifelong learners. In B. Heerman, C. Enders, and E. Wine (Eds.). New Directions for Community Colleges: Serving Lifelong Learners. San Francisco: Jossey Bass. pp. 23-29.

Cowley, W. H. (1938). Nourishing future alumni. The Educational Record. 19, 494-498.

Cross, K. P. (1981). Adults as Learners. San Francisco: Jossey Bass.

Darkenwald, G. \& Merriam, S. (1982). Adult Education: Foundations of Practice. New york: Harper and Row.

Decrow, R. (1975). New Learning for Older Americans. Washington, D. C.: The Adult Education Association of the U.S.A.

Eurich, N. P. (1985). Corporate Classroom: The 
Learning Business. New Jersey: The Carnegie Foundation for the Advancement of Teaching.

Evans, R. \& Skinner, B. F. (1968). The Man and His Ideas. New York: Dutton.

Farmer, M. I. (1971). Counseling Services for Adults in Higher Education. Metuchen, N.J.: The Scarecrow Press, Inc.

Farmer, M. L. (1967). Student Personnel Services for Adults in Higher Education. Metuchen, New Jersey: The Scarecrow Press, Inc.

Fauguet, T. W. Recruiting older students to Baccalaureate colleges and Universities. (Doctoral Dissertation, The University of Florida, 1983).

Fuller, J. W. Continuing Education and The community College. Chicago: Nelson Hall.

Fuller, J. (December, 1971). Continuing Education by objectives. Journal of continuing education. pp. 175-179.

Gagne, R. M. (1965) . The Conditions of Learning. New York: Holt, Rinehart and Winston.

Geisler, M. P. \& Thrush, R. S. (1975). Counseling Experiences and Needs of Older Women Students. Journal of the national association of Women Deans, Administrators, and Counselors. 39, 3-8.

Gilder, J. (1980). Lifelong education: The Critical Policy Questions. In B. Heermann, C. Enders, and E. Wine. (Eds.). New Directions for Community Colleges: Serving Lifelong Learners. San Francisco: Jossey Bass. pp. 69-86.

Gold, S. (1973). Diversity by Design. Carnegie commission on non traditional studies. San Francisco: Jossey Bass.

Gould, R. (1978). Transformations: Growth and Change in Adult Life. New York: Simon and Schuster. 
Goulet, I. R. \& Baltes, Paul B. (1970). Life-Span Developmental Psychology. New York: Academic Press.

Grabowski, S. M. (1976). Motivational and Participation Patterns. Klevins, Chester (Ed.). Material and Methods in Continuing Education. New York: Klevins Publications, Inc.

Grattan, C. H. (1959). American Ideas About Adult Education. 1710-1951. New York, Teachers College: Columbia University.

Gross, $R$. The Life Long Learner. New York: Simon and schuster.

Grownups on Campus. (December, 1981). Newsweek. p. 72 .

Heerman, B. (1980). "On Transforming a Traditional College." In B. Heerman, C. Enders, and E. Wine. (Eds.). New Directions for Community Colleges: Serving Lifelong Learners. San Francisco: Jossey-bass. pp. 87-93.

Henchinger, F. (1975). Education's New Majority. Saturday Review, 2, 14-18.

Hesburgh, T. M., Miller, Paul A. \& Wharton, Clifton R. (1973). Patterns for Lifelong Learning. San Francisco: Jossey-Bass.

Hill, W. F. (1964). Contemporary Developments Within Stimulus-Response Learning Theory. In Ernest Hilgard (Ed.). Theories of Learning and Instruction. University of Chicago: Chicago Press.

Hirshorn, M. W. (19088). "Students over 25 found to make up 45 percent of campus enrollments." Chronicle of Higher Education A. 35.

Horney, K. (1967). Feminine Psychology. New York: Norton and Co.

Houle, C. O. (1963). The Inquiring Mind. Madison, WI: The University of Wisconsin Press. 
Houle, c. O. (1964). Continuing your Education. New York: McGraw-Hill, Inc.

Houle, C. O. (1973). The External Degree. San Francisco: Jossey-Bass.

House, R. (1983). Standards of Practice in continuing Education: A status study. (Doctoral dissertation. North Carolina State University at Raleigh, 1983). Dissertation Abstracts International. (DA 8402100).

Irish, G. H. (1978). Persistence and Dropout in Adult Education. New York: Columbia University Press.

Jacobson, R. L. (February, 1973). "Colleges Are Not Meeting Needs of Adults." Chronicle of Higher Education.

Jung, c. (1971). The stage of Life. In Campbell (Ed.). The Portable Jung. New York: Viking Press.

Kidd, J. R. (1973) . How Adults Learn. New York: Association Press.

Knowles, M. S. (1982). The Modern Practice of Adult Education. New York: Cambridge, the Adult Education Company.

Knowles, M: (1967). Handbook of Adult Education In The United States. Washington, D. C. Adult Education Association of U.S.A.

Knowles, M. S. (1973). The Adult Learner: A Neglected Species. Houston: Gulf Publishing Co.

Knox, A. B. (1980). Developing, Administering, and Evaluating Adult Education. San Francisco: Jossey-Bass.

Knox, A. B. (1973). Helping Adults To Learn: University of Illinois. Champaign, IIl: Office for The study of Continuing Professional Education. 
Knox, A. B. (1977). Adult Development and Learning. San Francisco: Jossey-Bass, Inc.

Knox, A. B. Critical Appraisal of The Needs of Adults For Educational Experience As a Basis for Program Development. Document Resume. Eric Clearinghouse on Adult Education. Dekalb University of Northern Illinois.

Kreitlov, B. W. (1976). Adult learning patterns. Chester Klevins (Ed.). Materials and Methods in Continuing Education. New York: Klevins Publications, Inc.

Langerman, P. D. \& Smith, D. A. (1979). Managing adult and continuing education. Programs and staff. National Association for Public Continuing and Adult Education.

Lengrand, P. (1975). An Introduction to Lifelong Education. Paris: Unesco Press.

Letchworth, G. E. (1970). Women who return to college: An identity-integrity approach. Journal of college student personnel, 11 . 103-106.

Levinson, D. (1978). The Seasons of A Man's Life. New York: Knopp.

Maslow, A. (1971). The Farther Reaches of Human Nature. New York: The Viking Press, Inc.

Maslow, A. (1951). Motivation and Personality. New York: Harper Brothers.

Mead, George H. G. Individuality in the Nineteenth Century. Movements of Thought in The Nineteenth Century. Chicago: University of Chicago Press.

Mills, D. Q. (1985). Planning With People In Mind. Harvard Review (4). Boston. 97-105

Minnis, J. R. (1975). The concept of Lifelong Learning. Florida State University.

Nadler, L. (1984). The Handbook of Human Resource 
Development. New York: Wiley-Interscience Publishing Co.

Neugarten, B. L. (1968). Adult Personality: Toward a Psychology of The Iife Cycle. Middle Age and Aging. Chicago: University of Chicago Press.

Neugarten, B. L. \& Datan, Nancy (1973). Sociological Perspectives of The Lifecycle. Life-Span Developmental Psychology. New York: Academic Press.

Neugarten, B. I. \& Brown-Rezanka, I. (1978). Mid Life Women in the 1980s, on Women in Midlife-security and Fulfillment. Washington, D.C. A compendium of papers submitted to the select committee on aging. U.S. House of Representatives, Ninety-Fifth Congress.

Participation in Adult Education (May, 1985). U. S. Department of Education, Center for Statistics.

Peterson, D. G. (1975). The Conservation of Human Talent. The American Psychologist. Vol. 12, No. 3. pp. 134-144.

Peters, J. M. \& Boshler, Roger (1976). Adult Needs, Interests, and Motives. Materials and Methods In Continuing Education. New York: Klevins Publications.

Piaget, J. (1972). Intellectual Evolution From Adolescence to Adulthood. Human Development, $\underline{15}$.

Rauch, D. B., Vief, G. (1970). New Priorities for Adult Education. New York: The MacMillan Company.

Rauch, D. B. (1972). Age not Learning Handicap. School of Education Newsletter. University of Wisconsin. Vol. 5. No. 3 .

Rawlins, M. (1981). Recommendations for Changes in Services Available to Adult Students. Unpublished manuscript. Lincoln, NE: University of Nebraska. 
Rawlins, M. E. \& Lenihan, G. O. (1982). A Cooperative Endeavor for Integrating Re-entry Adults in a Four-Year University. Journal of College Student Personnel, 23. 531-537.

Reisser, I. (1980). Approaches to recruiting the adult learner. In W. Heerman, C. Enders, and $\mathrm{E}$. Wine (Eds.). New Directions for Community Colleges: Serving lifelong Learners. San Francisco: Jossey-bass. pp. 47-55.

Riggs, J. A. (1981). Strengthening collegiate adult student services. In J. C. Votruba (Ed.). Strengthening Internal support for continuing Education. San Francisco: Jossey-Bass. pp. 47-55.

Roberts, N. M. K. (1978). The Human Developmental Needs of Adults Across the Lifespan With Implications For Higher Education. Thesis. Madison: University of Wisconsin.

Rogers, C. R. (1969). Freedom to Learn. Columbus: Charles E. Merrili Publishing Co.

Rogers, J. (1973). Adult Learning. Baltimore MD: Penguin Books, Inc.

Ryan, K., Johnston and Newman, Katherine (1977). An interview with Ralph Tyler. Phi Delta Kappan. Vol. 58. No. 7 .

Scott, R. \& Holt, I. (1980). The new wave: A college responds to women returness. Phi Delta Kappan, 58. 338-339.

Silling, M. A. (October, 1984). Student services for Adult Learners. Paper presented at the Annual Conference of the Willilams Midwest Region Academic Affairs Administrators. Dayton, $\mathrm{OH}$.

Sinick, D. (1976). Guest editor's introduction. Personnel and Guidance Journal. Vol. 55. No. 3

Stalford, C. B. (Ed.) (1978). Adult Learning Needs and The Demand for Iifelong Learning. Washington, D.C.: U. S. Government Printing office. 
Thorndike, E. I. (1932). The Fundamentals of Learning. New York: Teachers College, Columbia University.

Thorndike, E. L. (1913). Educational psychology. The psychology of learning. Vol. 2. New York: Teachers College, Columbia University. p. 4.

Title, C. K. \& Denker, E. R. (1980). Returning Women Students in Higher Education. New York: Praeger.

Tolman, E. C. (1932). Purposive Behavior in Animals and Man. New York: Appleton-Century-Crofts.

Tough, A. (1971). The adult's Learning Projects. Toronto: The ontario Institute for studies in Education.

Weathersby, R. (1980). Education for adult development: The components of qualitative change. New Directions for Higher Education. San Francisco: Jossey-Bass.

Wedemeyer, C. A. (1974). Three stages of Learning. Unpublished paper. 
$V I T A$ 


$$
\begin{gathered}
V I T A \\
\text { ROBERTO BARRAGAN, JR. }
\end{gathered}
$$

\section{PERSONAL:}

Date of Birth: October 14, 1942

Place of Birth: Havana, Cuba

Marital status: Single

EDUCATION :

M.S.Ed. Adult Education Human Resource Development, 1987

Florida International University

B.A. English, 1964

Bethune-Cookman College

\begin{tabular}{|c|c|}
\hline $\begin{array}{l}1982- \\
\text { Present }\end{array}$ & $\begin{array}{l}\text { Director of Admissions and Recruitment } \\
\text { Bethune-Cookman College }\end{array}$ \\
\hline $1980-82$ & $\begin{array}{l}\text { Dean of Student Affairs } \\
\text { Florida Memorial College }\end{array}$ \\
\hline $1977-80$ & $\begin{array}{l}\text { Director of Admissions, Financial Aid, } \\
\text { Assistant to the President }\end{array}$ \\
\hline $1973-77$ & $\begin{array}{l}\text { Director of Student Affairs } \\
\text { A Better Chance Incorporated }\end{array}$ \\
\hline $1972-73$ & $\begin{array}{l}\text { Assistant Director } \\
\text { Consortium on Admissions and } \\
\text { Financial Aid }\end{array}$ \\
\hline $1969-72$ & $\begin{array}{l}\text { Assistant Director, Bureau of Student } \\
\text { Aid } \\
\text { Princeton University }\end{array}$ \\
\hline $1968-69$ & $\begin{array}{l}\text { College Admissions Counselor } \\
\text { New York College Bound Corporation }\end{array}$ \\
\hline $1964-68$ & $\begin{array}{l}\text { Group Worker } \\
\text { New York City Mission Society }\end{array}$ \\
\hline
\end{tabular}

PROFESSIONAL EXPERIENCE: 
PROFESSIONAL ORGANIZATIONS:

Phi Delta Kappa Educational Fraternity

Kappa Delta Pi Honor Society in Education

omicron Delta Kappa Society

Southern Association of College Admissions Counselor, Florida

National Association of College Admissions Counselor

Florida Association of Collegiate Registrars and Admissions officers

American Personnel and Guidance Association

American Association for Higher Education

College Entrance Examination Board

Florida Association of Private Colleges and Universities Admissions officers

Florida Adult Education Association 